\title{
FORUM
}

\section{Heteroptera as Vectors of Plant Pathogens}

\author{
Paula L. Mitchell \\ Dept. Biology, Winthrop University, Rock Hill, SC 29733 USA
}

Neotropical Entomology 33(5):519-545 (2004)

Heterópteros Como Vetores de Patógenos de Plantas

\begin{abstract}
RESUMO - A habilidade de insetos picadores-sugadores em transmitir doenças para as plantas está intimamente relacionada ao modo de alimentação e ao tecido alvo. Os percevejos são considerados de importância econômica mínima como vetores de patógenos de plantas, embora tenham comportamento alimentar semelhante aos homópteros. Os modos de alimentação em Heteroptera incluem "dilaceração e bombeamento", penetração intracelular no tecido vascular, e um mecanismo de bomba osmótica para adquirir os conteúdos celulares sem penetrar a membrana celular. A relação entre a taxonomia dos heterópteros, modo de alimentação e o tipo de patógeno transmitido é explorada através de um levantamento bibliográfico. A transmissão por percevejos de fungos, bactérias, vírus, fitoplasmas e trypanossomatídeos flagelados é sumarizada. Os trypanossomatídeos flagelados de plantas parecem ser hospedados ou transmitidos exclusivamente por Pentatomomorpha (Lygaeioidea, Coreoidea, Pentatomoidea, e Pyrrhocoroidea). A transmissão de bactérias e fungos ocorre entre famílias de ambas infraordens, mas representantes de Miridae (Cimicomorpha) são mais associados com bactérias, enquanto os de Pentatomidae e Coreidae (Pentatomomorpha) predominam como transmissores de fungos. Alguns casos de transmissão de fitoplasmas e vírus são documentados, mas Cimicomorpha (tradicionalmente categorizados como alimentadores do tipo dilacerador-bombeador) estão representados mais freqüentemente do que o esperado, considerando-se a especificidade por determinados tecidos vegetais desses patógenos. A ênfase da literatura sobre a exclusividade ou predominância do papel dos homópteros como transmissores de doenças pode arrefecer o ímpeto inicial em estudar os percevejos como transmissores; entretanto, os resultados apresentados aqui indicam a necessidade de incluir os percevejos em levantamentos de potenciais transmissores de doenças.
\end{abstract}

PALAVRAS-CHAVE: Inseto vetor, percevejo, transmissão, trypanosoma, fitoplasma

ABSTRACT - The ability of piercing-sucking insects to transmit plant disease is closely linked to feeding mode and target tissue. The true bugs (Heteroptera) are generally considered to be of minimal importance as vectors of plant pathogens, although they share similar feeding behaviors with homopterans. Modes of feeding in Heteroptera include "lacerate-and-flush", intracellular penetration to vascular tissue, and an osmotic pump mechanism to acquire cell contents without penetrating the cell membrane. The relationship between heteropteran taxonomy, feeding mode, and the type of pathogens transmitted is explored through a literature survey of feeding behavior and vectoring capability. Transmission by true bugs of fungal pathogens, bacteria, viruses, phytoplasmas, and trypanosomatid flagellatesis summarized; no records exist of bugs transmitting spiroplasmas. Trypanosomatid flagellates of plants appear to be harbored or transmitted exclusively by Pentatomomorpha (Lygaeioidea, Coreoidea, Pentatomoidea, and Pyrrhocoroidea). Bacterial and fungal transmission occurs among families representing both infraorders of phytophagous Heteroptera, but Miridae (Cimicomorpha) are most closely associated with bacteria, whereas Pentatomidae and Coreidae (Pentatomomorpha) predominate in transmission of fungi. Few cases of transmission of phytoplasmas and viruses are documented, but Cimicomorpha (traditionally categorized as destructive lacerate-andflush feeders) are represented more frequently than expected, considering the tissue specificity of these pathogens. Literature emphasis on the exclusive or predominant role of homopterans as disease vectors may discourage initial investigations of true bugs; based on the results presented here, the necessity of including heteropterans in any survey of potential plant disease vectors is clear.

KEY WORDS: Insect vector, true bug, transmission, trypanosome, phytoplasma 
The ability of piercing-sucking insects to transmit plant disease is closely linked to feeding mode and target tissue. Heteroptera are generally considered of negligible importance as vectors of plant pathogens, although they share similar feeding behaviors with other hemipteran suborders. A few well-documented cases of heteropteran transmission (e.g., Piesmatidae) appear in textbooks, but for the most part, true bugs have not been considered efficient vectors (Carter 1973), especially in comparison to leafhoppers and aphids. Are heteropterans competent vectors that have been overlooked in disease transmission research, or do crucial differences in morphology or feeding behavior exist between the hemipteran suborders that prevent true bugs from transmitting the majority of pathogens? The objective of this review is to analyze records of Heteroptera as vectors of plant diseases, focusing on taxonomic relationships and feeding behaviors, to determine if mode of feeding can explain patterns of disease transmission.

Categories of plant pathogens considered in this review include viruses, prokaryotes (mollicutes, vascular-limited bacteria, and non-vascular-limited bacteria), fungi, and trypanosomatids. Insect-pathogen relationships described in the literature range from vague "associations" or "suspected" transmission, to facilitating entry via feeding wounds, to observation of the pathogen in the host insect, to fully established cases of experimental transmission. Isolation of a pathogen from an insect does not guarantee vectoring capability, nor does experimental transmission in the laboratory necessarily mean that the insect plays an economically important role in actual disease spread. Nonetheless, all levels of association were included in compiling the database for this review ${ }^{1}$. Literature records were traced to the original source when feasible, but extensive reliance has been placed upon earlier, thorough reviews focused on pathogens (e.g., Leach 1940, Agrios 1980, Camargo \& Wallace 1994) and bugs (e.g., McPherson \& McPherson 2000, Schaefer \& Panizzi 2000, Wheeler 2001). Each vector-pathogen association (including bacterial pathovars) was treated as a unique record, but multiple host plant associations for a given bug-pathogen relationship were ignored. Heteropteran taxonomic placement follows Schuh \& Slater (1995); the source for fungal species names is Kirk et al. (2004) and for bacteria, Schaad et al. (2001).

\section{Overview of Hemipteran Feeding}

All phytophagous hemipterans feed by penetrating plant tissues, using a stylet bundle composed of two inner maxillary and two outer mandibular stylets. Between the appressed maxillary stylets, saliva is pumped down one canal, and liquid food travels up the other. Few generalizations for the group can be made beyond this point: Sternorrhyncha, Auchenorrhyncha, and Heteroptera vary in structure, mechanics, physiology, and behavior of feeding. From the standpoint of pathogen transmission, four aspects of feeding behavior are of greatest import: salivation, size of stylet bundle and canals, preferred target tissue, and sensory ability.

Circulative transmission is intimately associated with the salivary glands; thus, gland structure, composition of the saliva, and salivation behavior are vital in determining vector relationships. Pentatomomorpha (and all homopterans) produce two types of saliva: gelling, from the lateral and/or anterior lobes of the salivary gland, and watery, from the posterior lobes (Miles 1968). Gelling saliva lines the path of the stylets as they progress through the plant tissue, forming a flange on the surface and a track, or "stylet sheath" within. Phytophagous Cimicomorpha (Miridae and Tingidae) produce only watery saliva, and no stylet sheaths (Miles 1968).

Heteroptera in general are larger than aphids and leafhoppers, and consequently their stylets are thicker. Size affects two aspects of pathogen transmission: diameter of infective particles that can pass through the canals, and damage to plant tissues into which the stylets pass during feeding. Aphids can insert their stylets into single sieve tube or epidermal cells without damage and their stylets frequently pass between cells to reach the target tissue (Pollard 1973). Infective particles such as viruses are thus effectively delivered to uninjured host cells (Nault 1997). The larger stylet bundles of Heteroptera and Auchenorrhyncha are more likely to take an intracellular path, causing damage to plant tissues en route.

Most aphids feed by piercing single phloem sieve tube cells and ingesting flowing cell contents; related groups such as adelgids feed on parenchyma (Pollard 1973). Auchenorrhyncha includes phloem-, xylem- and mesophyll feeders, although the vascular feeders tend to be most strongly associated with pathogen transmission. Among the Heteroptera, sheath-forming (Pentatomomorpha) and nonsheath-forming (Cimicomorpha) groups feed differently. A lacerate-and-flush method (Miles 1968) is associated with Cimicomorpha; stylet movements within the tissue are accompanied by the release of watery saliva, and the combination of physical destruction and salivary enzymes produces lesions and other visible evidence of feeding damage. A variant of this feeding mode, in which only enzymatic cell disruption occurs, has been termed "macerateand-flush" (Miles \& Taylor 1994). Some cimicomorphans, such as bryocorine mirids, may also feed in vascular tissue (Wheeler 2001).

Stylet sheath formation has been generally associated with vascular feeding (Backus 1988), but the sheath-forming Pentatomomorpha are not strictly sap feeders. Cobben (1978) considers the Pentatomoidea, Coreoidea and Piesmatidae to be the "most specialized sap feeders in the Heteroptera". Preferred target tissue in the Pentatomomorpha may be vascular, reproductive (mature seeds or developing endosperm), or mesophyll. For seed feeding, the lacerateand-flush mode is employed, and sheath formation is minimal. When bugs feed in the vascular tissues, a complete sheath is generated. Phloem cells may be punctured directly by the stylets; however, in some coreids, salivary sucrase creates

${ }^{1}$ The lists of insect-pathogen relationships upon which the figure and discussion are based are not presented in the text in the interests of space, but are given as a tabular appendix. 
an osmotic pump that empties phloem sieve tube and parenchyma cells without actual mechanical damage. In this type of feeding, the insect ingests fluid from the intercellular spaces, and the region of cell collapse is evident as a lesion (Miles 1959, 1987; Miles \& Taylor 1994).

Electropenetration graphs (EPG's) have been invaluable in interpreting feeding behavior of homopterans. Few heteropteran EPG's have been produced, but recent studies of the mirid Lygus hesperus Knight illustrate a long-duration ingestion waveform and a more common ingestion waveform punctuated by brief bouts of salivation, consistent with a lacerate-and-flush feeding mode (Cline \& Backus 2002). Published EPG results for the coreid Anasa tristis (De Geer) (Bonjour et al. 1991, Cook \& Neal 1999) illustrate labial dabbing and extended bouts of ingestion, possibly from vascular tissue.

Some form of ingestion/egestion behavior has been postulated for transmission of non-circulative pathogens (Harris et al. 1981). Aphids, lacking labial chemosensilla, penetrate into epidermal cells for brief ingestion/egestion, using the precibarial sensilla to assess the plant (Harris 1977). All Heteroptera and Auchenorrhyncha have chemosensilla on the rostral apex (Cobben 1978, Backus 1988) in addition to those in the precibarium. Labial dabbing, exuding watery saliva onto the plant surface and then ingesting it, and test probing are all used by bugs for sampling the potential host plant (Backus 1988). Frequent test probes followed by precibarial uptake have been observed in $L$. hesperus feeding (Cline \& Backus 2002). Egestion at the end of a feeding bout has been reported for a pentatomid (Risk 1969, cited in Harris et al. 1981). Thus, despite differences, Heteroptera do share with homopterans some behaviors associated with pathogen transmission.

\section{Viruses}

In the early years of plant pathology research, the term virus simply referred to the unknown: a presumed infectious agent that could not be seen, cultured, or removed with a bacterial filter. Not surprisingly, many early reports of "virus" transmission turned out to be something else: spiroplasmas, phytoplasmas, or the result of direct damage to plant tissue. The latter was particularly a problem with true bugs, whose feeding often creates cankers or lesions. Thus, early transmission studies were confounded by the inability of researchers to distinguish "viral" symptoms from those of direct bug damage. Thus, as noted by Wheeler (2001), most published compendia of virus vectors ignored early reports of Heteroptera; only the well-established relationship between Piesmatidae and beet diseases was accepted. Harris (1981) considered all reports of virus transmission by mirids and lygaeids to be suspect, dismissing these incidents as probable mechanical injury from clawing. Similarly, Carter (1973) did not consider any literature records of mirids as virus vectors to be authentic. However, more recent reports of at least one verified mirid transmission (Gibb \& Randles 1991) suggest that this blanket dismissal may have been premature. Only the more recent literature will be discussed here; Wheeler (2001) presents a thorough summary of the earlier work with mirids, including both putative transmission and failure to transmit viruses.

Two species of Piesma are associated with beet diseases: Piesma quadratum (Fieber) in Central Europe and P. cinereum (Say) in the United States. Beet leaf curl disease (Rübenkräuselkrankheit) is caused by a rhabdovirus and was at one time economically devastating in Germany and Poland, reducing sugar content and overall yield (Proeseler 1980). The virus is concentrated in phloem parenchyma cells of the leaf and storage parenchyma cells of the beet (Eisbein 1976), and is transmitted in the saliva of the bug. Virus particles have been observed in the salivary glands, and are also found in the midgut, feces, and haemolymph. Both nymphs and adults of $P$. quadratum can transmit, but the long latent period generally exceeds the nymphal development time. Bugs remain infective for life, and the virus can overwinter in the vector; thus, transmission is propagative and persistent (Proeseler 1978, 1980). Beet savoy, a disease with similar symptoms (vein clearing, leaf curling, and stunting), occurs sporadically in eastern and central North America but has little or no economic impact because of the low incidence (Proeseler 1980). Consequently, it has not been as thoroughly studied as leaf curl disease and the causative agent remains unknown, although generally listed as a virus (e.g., Nyvall 1999) or suspected virus (e.g., Ruppel 2003). Overwintered, field-collected $P$. cinereum are capable of transmitting savoy (Schneider 1964), but the bug is a relatively inefficient vector (Proeseler 1980).

An unusual case of virus transmission was investigated by Gibb \& Randles $(1988,1989,1990,1991)$, which appears to correspond to no previously recognized form of aphid or leafhopper transmission. Engytatus (= Cyrtopeltis) nicotianae (Koningsberger) transmits velvet tobacco mottle and several other viruses in Australia. Virus can be detected in gut, haemolymph, and feces (but never salivary glands) of nymphs and adults after a short acquisition period, and it is transferred by gravid females to eggs. Transmission is neither propagative nor circulative (in the traditional sense of salivary gland involvement), but the extended infective period ( 9 days) is uncharacteristic of non-persistent or semi-persistent transmission. These mirids fit neither the ingestion-egestion nor the ingestion-salivation models (Harris 1977), nor any of the revised transmission groups of Nault (1997); the combination of long infectivity and transstadial transmission without virus propagation and salivary gland involvement is unusual. Gibb \& Randles (1991) proposed a new mode of virus transmission - ingestion-defecation - coupled with ingestion-egestion to explain the process. Virus remains for an extended period in the mirid gut, and defecated material is pushed into the interior of the leaf during subsequent feeding.

It is frequently argued that homopteran mouthparts are best suited for virus dissemination because they are less injurious to plant cells (Nault 1997); for infection to occur a cell must both receive virus and remain functional and undamaged in the process. Lacerate-and-flush feeders such as mirids would therefore seem the least likely heteropterans to serve as virus vectors. In addition to physical destruction, the salivary secretions that accompany such feeding might also interfere with successful virus replication. Carter (1973) 
observes that these bugs are “...normally so violently toxic that local or secondary lesions from the feeding point are the rule". Nonetheless, E. nicotianae indubitably transmits virus. The question remains whether this is a single unusual case, or if transmission of viruses by mirids (and other heteropterans) should be re-examined.

The mirid and piesmid species discussed above represent situations in which a particular virus is associated with a single vector. Virus-vector associations are complex, and virus evolution is thought to be strongly constrained by vector specificity (Power 2000). Most aphid/virus vectoring relationships are tightly dependent, particularly for persistent, circulative transmission (Ammar 1994, Nault 1997). Power (2000) states that "no virus species is capable of being transmitted by insects from more than one family". Therefore, various other reported cases of virus transmission by Heteroptera seem unlikely, because both a bug and a homopteran are noted as vectors. In field cage studies in Latvia, Lygus rugulipennis Poppius and L. pratensis (L.) transmitted potato viruses for which aphids are the usual vector (Turka 1978). Mosaic-M (a carlavirus) and "potato virus L" (potato leafroll virus, a luteovirus) were transmitted by both bug species; however, potato mosaic-S was not. Visual symptoms were confirmed using electron microscopy for the mosaic viruses and indicator plants for the leafroll virus. Other workers in the former USSR and elsewhere have also reported potato disease transmission by lygus bugs (Wheeler 2001, and references therein). However, because of the very close vector specificity between luteoviruses and aphids, such reports have not been taken seriously. Similarly (although minimal data are provided), lygaeoid bugs (Nysius spp., Orsillidae) and two aphids are said to transmit Centrosema mosaic (VanVelsen \& Crowley 1961). Like the carlavirus, this potexvirus can also be mechanically transmitted. Finally, a recent review of longan witches' broom disease (Chen et al. 2001) reports that both longan psylla (Cornegenapsylla sinica Yang et Li) and the litchi stink bug, Tessaratoma papillosa Drury transmit the causative agent, a filamentous virus, among longan (Euphoria longan Lam.) trees and from longan to litchi (Litchi chinensis Sonnerat) (Koizumi 1995, Chen et al. 2001). Electron microscopy indicated presence of the virus in bug salivary glands. Both nymphs and adults are capable of transmission. These reports are intriguing; perhaps other long-held views regarding vector specificity of virus transmission need to be reconsidered.

\section{Prokaryotes}

Mollicutes. The Class Mollicutes consists of prokaryotic organisms without cell walls. Plant pathogens in this group are associated primarily with yellows, phyllody, stunting, and witches'-broom diseases. In earlier literature these pathogens were usually referred to as mycoplasma-like-organisms (MLO's), and in publications before 1967 they were incorrectly identified as viruses. Current accepted terminology uses the trivial names phytoplasma and spiroplasma. Transmission of these pathogens is persistent and propagative; vectors remain infective for life and the pathogen moves out of the midgut to multiply in the body cavity and the salivary glands before being transmitted via feeding to a new host plant (Fletcher et al. 1998). Spiroplasmas, helical mollicutes that can be grown in laboratory culture, have been more successfully studied than the non-cultivable phytoplasmas.

All known vectors of plant pathogenic spiroplasmas are leafhoppers, although other spiroplasmas, pathogenic and commensal, occur throughout Insecta and in vertebrates as well. Insect transmission of phytoplasmas is less restricted; vectors include Cicadellidae, Psyllidae, Fulgoroidea and Heteroptera, with the former predominating. A website devoted to tracking phytoplasmas and their vectors (Phytoplasma-vector.com 2004) lists 65 relationships between phytoplasmas and leafhoppers, compared with nine for fulgoroids (mainly Cixiidae), seven for psyllids, and four for true bugs.

Paulownia witches'-broom is a potentially lethal disease that ruins the quality of timber from the empress tree (Paulownia tomentosa [Thunb.] Sieb. \& Zucc. ex Steud.) and other Paulownia spp. throughout East Asia. The causal agent, one of the earliest identified phytoplasmas, is transmitted by the brown marmorated stink bug, Halyomorpha halys Stål (= H. mista Uhler), in Japan, Korea, and China (Hiruki 1999). Sieve tube cells and phloem parenchyma of infected roots and young shoots contain the pathogens (Doi \& Asuyama 1981). Bugs became infective after 10 days acquisition access followed by 30 days incubation, and electron microscopy indicated the presence of phytoplasmas in the salivary glands (Hiruki 1999, and references therein). Nymphs and adults are able to transmit from infected Paulownia to periwinkle (Okuda et al. 1998). $H$. halys is also listed as a vector of jujube witches'-broom (Phytoplasma-vectors.com 2004); however, transmission of this phytoplasma in China is generally attributed to the leafhopper Hishimonas chinensis Anufrive ( Koizumi 1995).

Lace bugs (Tingidae) transmit root wilt, a non-lethal but economically damaging disease of coconut palms in India (Mathen et al. 1990). Infective phytoplasmas were observed in salivary glands of adult Stephanitis typica (Distant) following a five day acquisition access period and 13-18 days incubation. Inoculation experiments using large numbers of adults were conducted in field cages and resulted in infection of coconut seedlings; conclusions were based on serological testing, electron microscopy, and eventual appearance of disease symptoms. Studies of feeding on coconut by this lace bug showed initial entry through stomata on the underside of the leaflet, and termination of the stylets in the phloem. However, the bug does not exclusively feed on phloem; it also ruptures cell walls in the mesophyll, drains the contents of palisade cells, and leaves feeding and damage marks visible on the surface of the leaflet opposite from entry (Mathen et al. 1988). Tingid feeding typically produces only stipple marks (caused by damage to palisade parenchyma); thus, these insects are generally considered unlikely, even questionable, disease vectors (Neal \& Schaefer 2000).

Early reports from Korea indicated that a mirid, Nesidiocoris tenuis (Reuter), could transmit paulownia witches'-broom (La 1968, cited in Doi \& Asuyama 1981), but this insect is presently considered only a "suspected" vector 
(Hiruki 1999), along with a berytid, Gampsocoris sp. Other mirid associations (L. rugulipennis/tomato stolbur and Halticus minutus Reuter/sweetpotato little leaf) are summarized by Wheeler (2001), who suggests that all records of mirids transmitting phytoplasmas may need verification.

Recent development of PCR detection techniques for phytoplasmas allows surveys of potential insect vectors to be conducted efficiently. Two such studies have implicated heteropterans as potential vectors. The witches'-broom disease of Protea spp., cultivated South African flowers, may be transmitted by a lygaeoid bug. Oxycarenus maculatus (Oxycarenidae) showed a positive response, along with two mite species and, surprisingly, a predatory (mite-feeding) anthocorid, Orius sp. (Wieczorek \& Wright 2003). DNA was extracted from whole, starved arthropods, so location of the phytoplasmas was presumably the salivary glands, haemolymph, or midgut epithelium, rather than the digestive tract lumen. Protea-feeding pentatomid nymphs tested in this study were negative. In another study, DNA sequence analysis determined that a phytoplasma was present in the lygaeoid Nysius vinitor Bergroth (Orsillidae), genetically similar but not identical to the phytoplasma DNA sequences associated with several papaya diseases (White et al. 1997). Both $N$. vinitor and $O$. maculatus are predominantly but not exclusively seed-feeders (Sweet 2000, Wieczorek \& Wright 2003); however, no mollicutes are known to be seedtransmitted (Fletcher et al. 1998). Presumably these bugs acquire infection by penetrating into vascular tissue, although it has been suggested that $O$. maculatus may introduce phytoplasmas into seeds if feeding is non-destructive (Wieczorek \& Wright 2003).

Piesma quadratum (Fieber) transmits the causative organism of beet rosette disease in Germany. This Old World bug, and its American relative, $P$. cinereum are also involved in transmission of beet viruses (see above, Viruses). Beet rosette, however, is not a viral disease. The causative agent has been variously described as a rickettsia-like-organism (RLO) in Germany (beet latent rosette disease, Nienhaus \& Schmutterer 1976) and a phytoplasma in Italy (rosette-disease, Canova et al. 1990) and the USA (beet latent rosette, Ruppel 2003). Identity of the vector insects in Italy and the USA is not confirmed. Transmission of rosette disease, therefore, will be treated in the next section (see below); based on published descriptions (Frosch 1983), the "RLO" agent of German beet latent rosette appears to be a fastidious phloemcolonizing bacterium.

Phloem-feeding would seem to be essential for phytoplasma vectoring capability. Piesma and Stephanitis, although feeding extensively on palisade cells, have been shown to penetrate to the phloem tissue; pentatomids (e.g., Halyomorpha), which produce salivary sheaths, can presumably also do so. Among the suspected vectors, Nesidiocoris spp. are unusual among mirids for their vascular feeding (Wheeler 2001). Mirids typically lacerate and flush; most lygaeoids, although capable of producing stylet sheaths, also lacerate and flush their preferred food (seeds). Isolation of phytoplasmas from Protea- and papaya- feeding lygaeoids is thus intriguing, but without transmission studies, further speculation is pointless.
The two confirmed cases of heteropteran transmission of phytoplasmas (Tingidae and Pentatomidae) indicate that movement of phytoplasmas in true bugs from the digestive tract lumen to the salivary glands does occur. Fletcher et al. (1998) argue that transmission of spiroplasmas may be restricted to Homoptera because of differences in the structure of the basal lamina of the midgut: amorphous and permeable in aphids and leafhoppers but grid-like with limited permeability in other orders. How phytoplasmas cross the various intestinal barriers remains unknown, but the presence of these organisms beyond the gut lumen is indicated in Stephanitis, Halyomorpha, and probably Oxycarenus.

Fastidious Vascular-Colonizing Bacteria. Originally described as rickettsia-like organisms, or RLO's, these small, rod-shaped, walled bacteria are restricted to either phloem sieve tubes or xylem elements. Fastidious xylem-limited bacteria are vectored by Cercopidae (spittlebugs) and Cicadellidae (sharpshooters), both xylem-feeders (Fletcher $\&$ Wayadande 2002). Transmission is non-circulative; in the case of Xylella fastidiosa, bacteria accumulate in the foregut and are egested into the host. Although coreids have been shown to penetrate frequently to xylem tissue of stems and petioles (Mitchell 1980, Neal 1993), no Heteroptera are dedicated xylem feeders, and not surprisingly none are reported as vectors of these organisms. In contrast, fastidious phloem-colonizing bacteria are vectored by insects from all the hemipteran suborders, including psyllids, leafhoppers, and true bugs; the mechanism of transmission varies from non-circulative to propagative.

Anasa tristis (De Geer), the squash bug, has recently been shown to transmit Serratia marcescens, the causal agent of cucurbit yellow vine disease (CYVD) (Bruton et al. 2003). This coreid feeds on cucurbit stems, leaves, and fruit. Leaf feeding injures epidermal cells and mesophyll, but stylet insertions reach the phloem (Beard 1940, Neal 1993). Deposition of saliva in collenchyma, parenchyma, and xylem cells suggests that squash bugs feed from a variety of plant cell types (Neal 1993). However, A. tristis will not feed from parafilm sachets or other diets traditionally used in hemipteran feeding research. Consequently, laboratory studies of pathogen transmission used cubes of squash fruit cortex that were vacuum-infiltrated with the pathogen (Bextine et al. 2003).

Unlike most phloem-colonizing bacteria, S. marcescens can be easily cultivated on artificial medium, although the strain associated with CYVD differs from reference strains of this bacterium in some metabolic and biochemical characters (Rascoe et al. 2003). The bacterium can be transmitted experimentally by puncture inoculation of young seedlings (Bruton et al. 2003) and by A. tristis, from squash cube to seedling squash in field cages (Bruton et al. 2003) and from squash cube to seedling pumpkin in the laboratory (Bextine 2001). Results of the latter study are consistent with noncirculative transmission similar to that of Xylella fastidiosa, in which bacteria accumulate in the foregut during a latent period. Although PCR testing showed $S$. marcescens to be present in the haemolymph of some individuals, this condition was not necessary for transmission to occur. However, 
extended inoculation access periods (up to 20 days after acquisition) indicated that stylet contamination alone was not responsible. Nymphs (second instar) could acquire the bacterium but did not transmit (Bextine 2001). Overwintering adults harbor the pathogen and can transmit it to seedling squash plants following termination of diapause (Pair et al. 2004). Disease transmission, coupled with direct damage to cucurbit crops, has dramatically raised the pest status of $A$. tristis (Pair et al. 2004), which now appears to be an economically important vector of cucurbit yellow vine disease.

The causative organism of beet latent rosette disease, originally described as an RLO (Nienhaus \& Schmutterer 1976), is most likely a fastidious phloem-limited bacterium. In the beet plant, infective organisms are reported only from the phloem sieve tube cells, not in companion cells, parenchyma, or xylem. Both adults and nymphs of the piesmid, $P$. quadratum, can be vectors. Transmission is persistent throughout the lifetime and propagative, with a 10-30 day latent period (Proeseler 1980, Frosch 1983). Feeding by $P$. quadratum resembles that of tingids: salivary sheaths terminate in the phloem, but damage to individual parenchyma cells results in spotting of the leaf undersurface (Proeseler 1980). Observation of bugs with electron microscopy at repeated intervals (after a 4-d acquisition feeding period as fifth instars) showed infected salivary glands by day 10 . The organism was present in the midgut epithelium by day 6 and later in the fat body and haemolymph, and was described as multiplying in the midgut epithelium and flooding the intestinal lumen of P. quadratum (Frosch 1983). The long latent period and occurrence of these organisms throughout the vector are very different from the non-circulative transmission seen in A. tristis, and more closely resemble that reported for psyllid and leafhopper transmission of other fastidious phloem-limited bacteria.

It is worth noting that all confirmed cases of phloemlimited prokaryotes transmitted by Heteroptera involve bugs that feed frequently but not exclusively on phloem. The one predatory species found to harbor phytoplasmas (Cimicoidea, Orius sp.) most likely represents indirect acquisition from eating infected mites. Even if Orius is excluded, both Cimicomorpha and Pentatomomorpha are represented among the potential and confirmed vectors; apparently stylet sheath formation, strongly associated with effective phloem sievetube feeding, is not necessary for transmission of these pathogens.

Non-Fastidious Bacteria. The majority of pathogenic bacteria are not strongly dependent on insect vectors. Bacteria invade through wounds or natural openings (e.g., stomata); unlike fungi, they cannot penetrate plant tissue directly (Goto 1992). Thus, transmission may be facilitated when insect feeding damage creates infection courts or externally contaminated mouthparts introduce bacteria into feeding punctures; less often, bacteria are harbored internally. Much of the early economic literature includes passages like the following, describing damage on tomato caused by the coreid Leptoglossus cinctus (Herrich-Schaeffer): “...directly inserting rot-producing spores or bacteria into the fruit with their beaks, or at least breaking the surface of the fruit so that such spores and bacteria can readily gain entrance" (Wolcott 1933). However, few entomologists who noted these interactions actually cultured the presumed introduced bacteria, or identified the pathogen. Complicating the situation further is the similarity of disease lesions and those induced directly by heteropteran feeding, particularly mirids (Wheeler 2001). Thus, many older literature records implicating Heteroptera in transmission of bacterial diseases represent only association, rather than experimentally validated transmission or isolation.

One notable exception is a study of microorganisms associated with the stink bug, Nezara viridula (L.) (Ragsdale et al. 1979). Feeding stink bugs transferred four types of fungi and 31 bacteria; five of these (Pseudomonas spp. and Curtobacterium [as Cornyebacterium] spp.) were pathogenic, causing leaf spots and vein necrosis of soybean. Spread of most bacterial spots and blights (Pseudomonas and Xanthomonas spp.) is attributed to rain, splashes, tools, and handling, as well as insects; penetration occurs through natural openings (e.g., stomata) as well as wounds (Agrios 1997).

Boll rot of cotton is caused by both fungal and bacterial pathogens, and many cotton-feeding insects have been implicated in transmission. However, a distinction is not always made in the entomological literature between the bacterium (formerly Bacillus gossypina, now Xanthomonas campestris malvacearum) and several pathogenic fungi (see below, Fungi). Transmission of this X. campestris pathovar, which also causes angular leaf spot, black arm, and bacterial blight of cotton, is attributed to several mirid species (Wheeler 2001, and references therein), and considered highly probable for pentatomids, lygaeids, largids, pyrrhocorids, and coreids (Morrill 1910), although whether the relationship primarily represents vectoring (i.e., inoculation during the feeding process) or only wounding to produce an infection court is undetermined. Unidentified bacteria in the genera Pseudomonas and Xanthomonas have been cultured from the salivary glands of field-collected cotton fleahoppers, Pseudatomoscelis seriatus (Reuter) (Martin et al. 1987) and these mirids can transmit $X$. campestris malvacearum to young cotton plants after being inoculated artificially by laboratory feeding (Martin et al 1988). A related disease, common blight of beans (X. campestris phaseoli) is not transmitted by lygus bugs (Hawley 1922, cited in Wheeler 2001), but can be transmitted to cowpea by $N$. viridula dipped in bacterial suspension; field-collected bugs carried pathogenic xanthomonads on their bodies but did not transmit blight to caged plants (Kaiser \& Vakili 1978). Bacterial leaf blight of rice (X. campestris oryzae) spreads mainly by rain or irrigation water (Goto 1992). Unidentified bacteria cultured from stylets and saliva of the rice stink bug, Oebalus pugnax (F.) failed to induce kernel discolorations on rice panicles when artificially inoculated; isolates obtained from field-collected discolored rice panicles in this study were probably Xanthomonas spp. (Lee et al. 1993). Black discoloration of rice grains, or "black rot" is associated with feeding by pentatomid bugs in Japan; bacterial isolates from affected grains included Erwinia herbicola (= Xanthomonas 
itoana). Damage with a needle during the milky ripe stage resulted in blackening of grains and infection by this bacterium (Tanii et al. 1974), suggesting that the bug punctures provide a court of entry.

Vascular wilts (Clavibacter, Erwinia spp.), in which the bacteria invade the xylem, are more closely associated with insect vectors. Erwinia tracheiphila (cucurbit wilt), for example, is transmitted by cucumber beetles, whereas $E$. amylovora (fire blight) is associated with a wide variety of insects. Bees and flies become contaminated through contact with oozing cankers, and then spread the disease to flowers, but leaf and twig infections result from wounding (Agrios 1997). Piercing-sucking mouthparts of bugs would seem likely candidates for transmission of the latter type (Carter 1973). Fourteen species of mirids have been associated with or implicated as vectors of fire blight in apple and pear (Wheeler 2001, and references therein). Transmission by Lygus elisus Van Duzee and L. lineolaris (Palisot de Beauvois) has been confirmed in pear using field cage tests, but infection was limited to the fruits and no evidence of feeding or disease was found on shoots or leaves. This suggests that lygus bugs may not be involved in shoot blight transmission (Stahl \& Luepschen 1977). Feeding by non-contaminated Lygus spp. also created infection courts on the fruit, which significantly increased disease rate when atomized inoculum was applied (Stahl \& Luepschen 1977); such infection courts may be more important than direct vectoring, because of the prevalence of E. amylovora in external cankers. Wheeler (2001) provides an excellent compilation of the literature on mirid involvement with fire blight, and notes that the role of these insects in transmission of shoot blight needs additional study.

Transmission of other Erwinia species has been reported, but further research is needed. Stewart's wilt of corn, (Erwinia stewartii), primarily associated with flea beetles, is not vectored by mirids (Goto 1992, Wheeler 2001); attempts to isolate this bacterium from other bugs, including Anthocoridae, Nabidae, Cydnidae, Pentatomidae, Lygaeidae, and Coreidae, were equally unsuccessful (Harrison et al. 1980). For soft rots, only one case of heteropteran transmission is reported. Lygus lineolaris is considered an economically important disseminator of soft rot of celery (Erwinia carotovora carotovora) under conditions of high humidity, although it is difficult to separate the effects of direct bug damage from effects of disease (Richardson 1938).

Plant bug involvement has been investigated in two other vascular wilt diseases, both caused by Clavibacter michiganense (formerly Cornyebacterium): ring rot of potato (C. m. sepedonicum) and tomato canker (C.m. michiganense). All attempts to isolate the latter from $L$. lineolaris were unsuccessful, and no transmission occurred from diseased to healthy plants (Ark 1944). In contrast, L. lineolaris has been implicated in transmission of ring rot of potato (Duncan \& Généreux 1960, cited in Wheeler 2001) (although secondary transmission by insects is of minimal economic importance compared with primary spread from infected tubers [Goto 1992]). The erratic transmission of vascular wilts by mirids is intriguing. In both fire blight and tomato canker, the bacterium resides epiphytically on the plant surface and oozes to the surface of cankers, yet plant bugs are associated only with fire blight. Secondary transmission of tomato canker is attributed to rain splash, agricultural implements, and wounding during handling, rather than insect feeding (Goto 1992, Agrios 1997).

Overall, transmission of non-fastidious pathogenic bacteria is associated with both Cimicomorpha and Pentatomomorpha (Fig. 1), and most reported cases involve either fire blight or cotton boll rot. Transmission is more often related to wounding (allowing subsequent entry of epiphytic or waterborne bacteria) than to direct vectoring. Mirids far outnumber other families (Fig. 1), suggesting that bacterial transmission is enhanced by the more destructive lacerateand-flush mode of feeding.

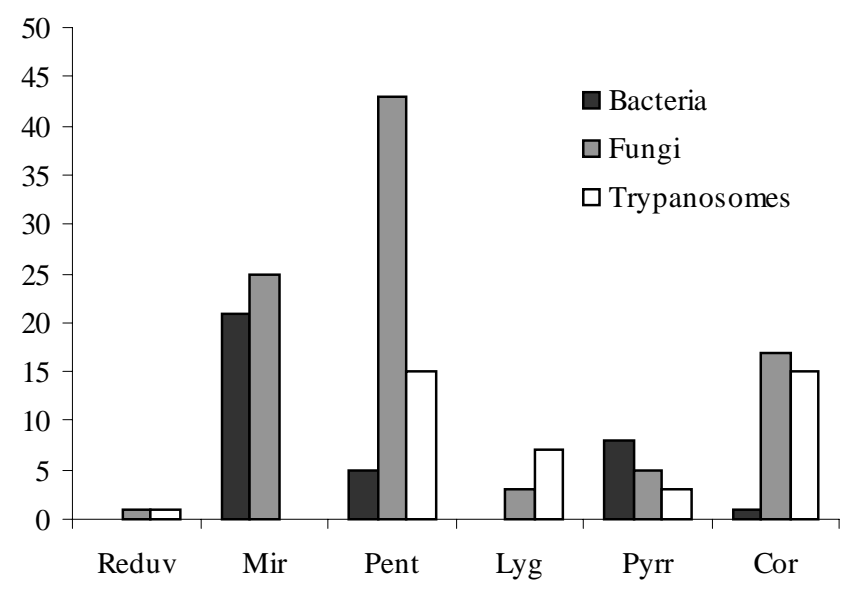

Figure 1. Frequency of association of heteropteran species with transmission of non-fastidious bacteria, fungi, and trypanosomes, arranged by superfamily: Reduvioidea, Miroidea, Pentatomoidea, Lygaeoidea, Pyrrhocoroidea, and Coreoidea.

\section{Fungi}

Fungi represent by far the largest group of plant pathogens. Fungal spores may be disseminated by water, wind, or insects, and entry into plant tissues is aided by insect damage (Agrios 1997). Heteroptera have been associated with a variety of fungal diseases, including tree cankers, leaf spots, pod and boll rots, and grain and legume decay (Agrios 1980). Most of the fungi involved are Ascomycetes. In some cases the association simply involves creation of an infection court through wound lesions or open stylet sheaths, as in bacterial transmission, but more frequently, the bugs are directly implicated in vectoring, or represent the primary facilitator of spore transmission.

The two most intensively studied fungal diseases associated with Heteroptera are stigmatomycosis (citrus, cotton, pistachio, soybean, lima bean, and coffee) and pecky rice. Both of these involve direct feeding damage to seeds or grain coupled with fungal infection; often in practice the two components are difficult to separate. In other crops, including annatto, cacao, cassava, and oil palm, bug feeding lesions provide an essential entry point for fungal spores but the 
insect itself is not necessarily the source of the pathogen.

Infection by the yeasts Nematospora coryli Peglion and Ashbya (=Nematospora) gossypii (S. F. Ashby \& W. Nowell) Guillierm. in association with hemipteran feeding was referred to as stigmatomycosis in the early years of research. Ashby \& Nowell (1926) define it as "characteristic injury resulting from inoculation of plant tissue by fungi through the feeding action of piercing-sucking insects". On pistachio, this term is still commonly used (Michailides \& Morgan 1990), but other terms are used for cotton (internal boll disease), beans (yeast spot), tomato (fruit rot), citrus (fruit lesions), and coffee (bean rot). Seventeen pentatomid species, six coreids, two scutellerids, two lygaeiod bugs, two alydids, and at least seven pyrrhocorids are associated with this disease. Interestingly, a lygus bug that was tested failed to transmit (Daugherty 1967). The cotton stainer (Dysdercus intermedius Distant), the green stink bug (Acrosternum hilare [Say]) on soybean, and the leaffooted bug (Leptoglossus gonagra F.) on citrus, have been most thoroughly studied.

Citrus fruits in Cuba are damaged by N. coryli, transmitted by $L$. gonagra adults and to a lesser extent by $N$. viridula. In the juice vesicles fed upon by these insects, asci, ascospores, and vegetative cells are visible; the oranges develop yellowstained lesions and are unmarketable. Dissected bugs had vegetative cells of $N$. coryli in the proctodaeum of the digestive tract, but none in the head, stomodaeum, or mesenteron (Grillo \& Alvarez 1983). The diameter of the salivary duct (8.32 ìm) and the food channel (12.48 ìm) of $L$. gonagra is insufficient to allow passage of these vegetative cells. Subsequent research (Dammer \& Grillo 1990) showed both $N$. coryli and A. gossypii to be present in heads and mouthparts of a high proportion of adults (51 and 43\%) as well as nymphs of L. gonagra. The same combination of fungi causes coffee bean rot, and is transmitted by Antestiopsis spp. (Pentatomidae) feeding on endosperm of unripe berries (Le Pelley 1942). Leaffooted bugs and pentatomids have also been implicated in transmission of pistachio stigmatomycosis, caused by $N$. coryli and possibly Aureobasidium pullulans (de Bary) G. Arnaud. Bug feeding alone causes necrotic lesions on the kernel, but these do not induce the rotting ("wet, smelly, rancid, slimy appearance") characteristic of stigmatomycosis (Michailides \& Morgan 1990, 1991).

The association between soybean leaf spot and pentatomid bugs is described as intimate, with the fungus dependent on the bug for transmission. Punctures simulating insect feeding do not result in incidental transmission (Daugherty 1967). However, reports of the presence of fungal spores internally in pentatomids have been contradictory. Leach \& Clulo (1943) isolated $N$. coryli readily from the surface of Acrosternum hilare, but not from the internal organs. These authors noted that the food channel of the stylets rarely exceeded $12 \mathrm{im}$ whereas mature cells of the fungus measured 10-20 ìm, and therefore they considered the association to be most likely mechanical and external. Daugherty (1967) isolated $N$. coryli from macerated heads, and Foster \& Daugherty (1969) cultured the yeast from stylets $(36 \%)$, salivary receptacles $(53 \%)$, and hindgut $(20 \%)$ of adults; nymphs were also found to carry the fungus. Clarke
\& Wilde (1970) inoculated bugs artificially by feeding them a yeast suspension, and found that adult $A$. hilare could retain the pathogen for 90 days (greater than the average longevity of this bug), and that molting nymphs lost their infectivity. $N$. coryli was also obtained from fecal deposits; it passes through the alimentary canal of $A$. hilare and remains viable (Clarke \& Wilde 1970).

Ashbya gossypii causes internal boll disease of cotton throughout the tropics, and is strongly associated with cotton stainers in the genus Dysdercus. Concurrent infection with $N$. coryli is common (Frazer 1944). Detailed studies with $D$. intermedius Distant showed the long, slender ascospores to be localized in the stylet pouches of the head, mainly at the base of the maxillary stylets (Frazer 1944). These invaginations are considered by Snodgrass to represent rearward extensions of the hypopharynx; thus, the contamination is internal. Spores can actually be ingested by all except first instars, but spores from the alimentary canal were not viable; only those retained on the chitinous lining of the salivary pouches could germinate. No contamination of the salivary glands was found; all viable spores are lost at each molt, and must be reacquired by feeding. Frazer (1944) considered transmission to be mechanical, with spores and mycelium carried as an external contaminant on the mouthparts and within the stylet pouches; however, the insect is obligatory for the spread of the fungus.

A related fungus, Holleya (= Nematospora) sinecauda (Holley) Y. Yamada damages mustard seed in Canada. This yeast is transmitted only by Nysius niger Baker (Orsillidae) although it was isolated from Lygus spp. and Nabis alternatus Parshley (Burgess et al. 1983). Several authors have speculated that yeasts such as $N$. coryli overwinter in bugs; Burgess \& McKenzie (1991) showed this not to be true in the case of $H$. sinecauda. $N$. niger overwinter as uncontaminated eggs, and the emerging spring generation is infected by feeding on seeds of a wild host plant.

$N$. coryli was isolated from pecky rice damaged by Oebalus pugnax (F.) (Daugherty \& Foster 1966), but this yeast is not considered to be the causal agent of the disease (Lee et al. 1993). Pecky rice refers to grains that are discolored and damaged due to stink bug feeding during the dough stage and the resultant entry of fungi (McPherson \& McPherson 2000, and references therein). An excellent discussion of the variety of symptoms associated with pecky rice, and the involvement of fungi and stink bugs, is provided by McPherson \& McPherson (2000). Fungi that induce the typical discoloration and have been isolated from the saliva and stylets of the rice stink bug include Curvularia lunata (Wakker) Boedijn and Alternaria alternata (Fr.) Keissler; other associated fungi include A. padwickii (Ganguly) M. B. Ellis, Fusarium oxysporum Schlect., and Cochliobolus miyabeanus (Ito \& Kuribayashi) Drechsler ex Dastur (= Bipolaris oryzae [B. de Haan]) (Lee et al. 1993). These fungi caused symptoms of pecky rice only if inoculated with a wire, mimicking insertion of bug stylets. Field plots from which rice stink bugs were excluded showed no symptoms of pecky rice. Thus, a "loose vector relationship" was postulated, with fungal infection occurring at the time of feeding (Lee et al. 1993). Stylet sheaths left by rice stink bugs may also provide access to the interior of the grain (Hollay et al. 1987). 
Other cotton boll and lint rots are associated with xanthomonad bacteria (see above), and several fungi. Unlike internal boll disease, several mirid species are associated with these pathogens, although no confirmed vector relationships are reported. Lygus hesperus Knight and Chlorochroa sayi (Stål) carry Aspergillus flavus Link. internally and externally (Stephenson \& Russell 1974). Creontiades pallidus (Rambur) carries Rhizopus stolonifer (Ehrenb.) Vuill. on its rostrum and may facilitate fungal entry (Soyer 1942, cited in Wheeler 2001). Similarly, L. lineolaris (Palisot de Beauvois) may transmit several boll rot fungi in addition to providing wound entry sites (Bagga \& Laster 1968). Alternaria and Fusarium spp have been isolated from the body and salivary glands of $P$. seriata, but it should be noted that this species is not a bollfeeder (Martin et al. 1987). Morrill (1910) considers it likely that boll anthracnose (Glomerella gossypini [Southw.] Edg.) is transmitted by various plant bugs feeding on cotton.

Lesions produced by both cimicomorphs and pentatomomorphs serve as important entry points for fungal pathogens in several serious crop diseases. Botryosphaeria blight, a devastating disease of pistachio, is associated with epicarp lesions caused by heteropteran feeding; large bugs (Leptoglossus clypealis Heidemann, Liorhyssus hyalinus [F.], Thyanta pallidovirens [Stål]), Acrosternum sp.) transmitted the fungus in cage studies (Michailides et al. 1998). Calonectria rigidiscula (Berk. \& Br.), which causes dieback of cacao, infects the trees through mirid lesions on stems. Bug lesions alone cannot kill the tree, but $50 \%$ of afflicted trees die if fungus enters the wound (Crowdy 1947). Carter (1973) describes this relationship as parallel with internal boll rot on cotton, but unlike Nematospora, no fungal spores have been found on or in the mirids' mouthparts (Kay 1961, cited in Wheeler 2001). On cassava, lesions of a coreid bug (Pseudotheraptus devastans [Distant]) facilitate invasion by Colletotrichum gloeosporioides Penz., a condition known as candlestick disease. Infected plants lose their leaves and the shoots wither, but in the absence of lesions, the fungus remains in a latent form on the stem surface. With very susceptible cultivars, bug punctures alone can cause defoliation, but in general the disease is attributed to the combined action of insect saliva and the fungus (Boher et al. 1983). A tingid bug, Letopharsa gibbicarina Froeschner, induces infestation by Pestalotiopsis spp., one of the most serious diseases of oil palm in Colombia. In the absence of bug feeding damage, this fungus attacks only older leaves, but if wounds to the parenchyma are present it can invade leaves of any age. Thus, through feeding and oviposition damage, the tingid is an efficient agent of dissemination for the pathogen (Genty et al. 1975, 1983). In most of the above cases, if the lesions are not present, the fungus does not present a problem. Thus, even if the fungal spores are not actually physically disseminated by the insect, bug control equates with disease control.

The preponderance of Pentatomomorpha in Fig. 1 reflects the close association between the larger Heteroptera and the yeasts $N$. coryli and A. gossypii. Size alone does not explain the much lower representation of Cimicomorpha, however, because several studies have shown that all coreid and pentatomid nymphal instars except the non-feeding firsts can acquire and transmit the ascospores. The long, thin asci (6-8 ìm diam) and small ascospores (2 ìm) (Wingard 1925, cited in Ragsdale et al. [1979]) would pass easily through the food (12 ìm) and salivary (11 ìm) canals of adult $N$. viridula (Ragsdale et al. 1979) and L. gonagra.

Preferred feeding site may explain some lack of transmission. Only the larger bugs transmit pistachio diseases because at the time of infection and kernel necrosis, the shell has hardened such that smaller mirids cannot penetrate (Michailides 1990, 1991). But it is unclear why feeding in the juice vesicles of oranges results in yeast infection (Grillo \& Alvarez 1983), but not the pulp of ripe coffee beans - only unripe beans are rotted, following bug damage to the endosperm (LePelley 1942). Fraser (1944) suggests that ascospores enter the salivary channel through leakage during stylet movement. Possibly, given the involvement with the salivary system, some connection exists between yeast transmission and salivation behavior. However, not all sheaths examined on rice actually penetrated the hull or the kernel (Hollay et al. 1987, and the lygaeid N. niger, feeding on seeds (Burgess \& McKenzie 1991), is unlikely to produce extended stylet sheaths. The association of Eremotheciaceae yeasts and pentatomomorphan bugs deserves further study.

\section{Trypanosomatids}

Trypanosomatid parasites of animals, including the bugtransmitted agent of Chagas' disease, are familiar and wellknown. Less attention has been paid to plant trypanosomatids (mainly Phytomonas spp.), which cause phloem necrosis of coffee, hartrot of coconut, and sudden wilt, or marchitez, disease, of oil palm in Central and South America. Recently a new trypanosomatid disease, affecting the ornamental plant Alpinia purupurata (Vieill.) K. Schum, was reported in the Caribbean (Camargo 1999). In addition to these phloeminhabiting pathogens, trypanosomatids inhabit lactiferous plants (e.g., Euphorbia, Asclepias) as (probable) commensals in the latex cells, and cause a lethal wilt in cassava (Dollet 1984). Others are found in the fruit, kernels, or seeds of various plants, and in flowers. Corn, mango, bergamot, annatto (Bixa orellana L.) and tomato are known hosts for Phytomonas spp. (Serrano et al. 1999a;); many other fruits also tested positive for Phytomonas and related genera (Conchon et al. 1989; Fernandez-Ramos et al. 1999). However, the effect of trypanosomatid infection on fruits is presently unclear, as is the taxonomy of these flagellates. Phloem-restricted trypanosomatids form a distinct genetic grouping separate from the latex- and fruit-inhabiting species (Dollet et al. 2000).

All known vectors of the plant-infecting (heteroxenic) trypanosomatids are true bugs, although monoxenic forms (e.g., Crithidia) are found in many insect orders. Early research was complicated by the presence of both heteroxenic and monoxenic species in the same individual; for example, the promastigotes of Phytomonas and Leptomonas cannot be separated morphologically. Plant trypanosomatids are found in the bug's digestive tract, haemolymph, and salivary glands (Dollet 1984), whereas the monoxenic species are found predominantly (but not exclusively) in the digestive tract (Wallace 1966). 
Transmission appears to be persistent and propagative, with the protozoan multiplying within the bug (Dollet 1984). The life cycle within the insect has been investigated in several cases. França (1920, reproduced in Leach 1940) dissected Dicranocephalus agilis (Scopoli) at various stages following infection and observed Phytomonas davidi in active division in the alimentary canal, a smaller "infective" form in the salivary gland, and both sizes in the latex of Euphorbia pinea L. (However, some of França's other observations most likely represent a monoxenic species from a different genus [Dollet 1984].) Similar results were obtained for Neopamera (= Pachybrachius) bilobata (Say); larger $P$. davidi promastigotes were found in Euphorbia (= Chamaesyce) hirta L. and in the insect's gut, while smaller ones were found in the salivary glands (McGhee \& Postell 1982). The path of transmission within the bug remains poorly understood. Early workers, who failed to see any flagellates in the haemocoel, assumed a backward transmission path from gut to salivary glands. Electron microscopy of $P$. serpens in the salivary glands of Phthia picta (Drury) suggests a route of infection via the haemocoel; flagellates appear in salivary glands and haemolymph one week after acquisition feeding (Freymuller et al. 1990).

Camargo \& Wallace (1994) summarized the trypanosomatids known to occur in Heteroptera, including vectors of Phytomonas. Their listing was updated by Camargo (1999) in an extensive discussion of trypanosomatid plant parasites. Six additional bug species, all from the Brazilian Amazon, have been confirmed as hosts of Phytomonas since 1999 (Godoi et al. 2002). Although nearly 100 bug species, in the families Miridae, Pentatomidae, Corimelanidae, Lygaeidae s.l., Pyrrhocoridae, Largidae, Stenocephalidae and Coreidae are known to harbor trypanosomatid flagellates of some kind, the majority of these are monoxenic (or unidentified). All proven vectors of plant trypanosomatids belong to the Pentatomomorpha: Lygaeoidea, Pentatomidae, and Coreoidea. A cassava-feeding tingid, Vastiga sp., was examined as a possible vector of $P$. françai, but was found to harbor no phytomonads in the alimentary canal (Kitajima et al. 1986, cited in Camargo 1999).

Lygaeoids are predominantly associated with lactiferous plants, although two coreoids, D. agilis (Stenocephalidae) and Niesthrea sidae (F.) (Rhopalidae) are reported to transmit parasites of Euphorbia spp. (Dollet et al. 1982; Iriarte 1928, cited in Solarte et al. 1995). Pentatomids, particularly Lincus spp., transmit the phloem-restricted causal agent of palm diseases, Phytomonas staheli (Camargo \& Wallace 1994, and references therein). The vector of $P$. leptovasorum, which causes phloem necrosis of coffee, is unknown, but pentatomids (L. spathuliger Breddin and Ochlerus spp.) are suspected (Stahel 1954, cited in Dollet 1984; Vermeulen 1963, cited in Camargo 1999). In fruit, coreids are most closely associated with transmission of phytomonads such as $P$. serpens and P. mcgheei (Jankevicius et al. 1989, 1993) although $N$. viridula was the first insect associated with tomato fruit flagellates (Gibbs 1957). Surveys for the presence of Phytomonas in the salivary glands and digestive tract of field-collected insects (Sbravate et al. 1989, Godoi et al. 2002) indicate that species of Coreidae most commonly harbor these flagellates, although vector relationships have not yet been established in most cases. Overall, Fig. 1 shows hosts of plant trypanosomatids to be exclusively pentatomomorphan, with one exception: the digestive tract of a single predatory reduviid tested positive for Phytomonas (Godoi 2000), reminiscent of the phytoplasmas isolated from predatory Anthocoridae. The predominance of coreids is of course partly due to the prevalence of these large bugs in Brazil, but it is worth noting that Miridae were sampled (Godoi et al. 2002) and tested negative.

Vector specificity of phytomonads is difficult to determine, because new species are currently not being named (Camargo 1999). Transmission of latex-inhabiting flagellates may be quite restricted; McGhee \& Postell (1982) tested a rhopalid and a second lygaeoid, but only N. bilobata transmitted $P$. davidi. Even congenerics may differ in vector capability. Two species of Oncopeltus can transmit $P$. elmassiani to milkweed under laboratory conditions (Ayala et al. 1975). However, only field-collected $O$. cingulifer Stål harbored flagellates in the haemolymph and salivary glands. This species, which feeds preferentially on vascular tissue, is considered to be the major vector in nature. In contrast, for the fruit-inhabiting $P$. serpens, both $P$. picta and $N$. viridula can be infected (Jankevicius et al. 1989), and the insect host range for this phytomonad may be broad. Fruit- and seedfeeding bug species predominate in surveys of field-collected hosts of Phytomonas; it seems probable that these represent vectors of $P$. serpens or other fruit-inhabiting forms, although the flagellate species and the vector relationships are still uncertain.

Camargo \& Wallace (1994) discuss the question of bug feeding preference with reference to transmission of latex flagellates. Oncopeltus fasciatus (Dallas) is a seed-feeding species, which penetrates to the phloem (Miles 1959) when feeding on milkweed stems but has not been shown to feed on latex cells. How, then, does it transmit a latex-limited parasite? These authors suggest that latex may provide a source of toxic cardenolides for protection against predators, but the possibility remains that infection of the latex is "incidental to phloem feeding" (Camargo \& Wallace 1994).

Plant trypanosomatids have posed problems historically in both identification and culturing, but recently developed PCR-based methods now permit various genera with similar morphological forms to be diagnosed and separated using smears on slides (Serrano et al.1999b). Minicircles of kinetoplast DNA also appear promising for separation of groups within Phytomonas (Dollet et al. 2001). These advances in research techniques will help to answer the many remaining uncertainties regarding these potentially important plant parasites.

\section{Conclusions and Directions for Future Research}

Facultative dissemination, which depends on the creation of infection courts, should be independent of feeding mode; any puncture or wound would be expected to provide adequate entry for bacteria and fungi. Yet these two pathogen groups differ dramatically in their relationship with 
heteropteran families (Fig. 1). The preponderance of mirids associated with non-fastidious bacteria may be simply a byproduct of extensive research on fire blight, but could also be a direct result of the more destructive mode of feeding characteristic of this family. Bug-fungus associations clearly outnumber all other relationships. Pentatomids predominate, although coreids, pyrrhocorids, and lygaeids extensively transmit yeasts. The resurgence of stigmatomycosis as a problem in pistachio and other crops may stimulate renewed research on the Erymotheciaceae, which appear to have a close, perhaps obligate relationship with the true bugs. Even for casual, rather than obligate associations, the potential economic impact of bug-enhanced transmission should not be ignored. Ragsdale et al. (1979) observe that "N. viridula has the potential to be a significant vector of both fungal and bacterial diseases of soybean".

Obligate transmission of pathogens such as viruses and fastidious prokaryotes is clearly not limited to homopterans. Unfortunately, this widely held misconception may bias the direction of field research. For example, during early screening for potential vectors of cucurbit yellow vine disease, researchers tested only leafhoppers, discarding all non-cicadellid insects from field collections (Bruton et al. 1998). The coreid A. tristis was eventually recognized as the vector. Similarly, after researchers investigating oil palm bud rot tested hundreds of thousands of Homoptera without results, the direction of research shifted to possible soil-borne transmission, with cydnid bugs in the genus Scaptocoris as potential vectors (de Franqueville 2001). Furthermore, upon reaching the "unlikely" conclusion that a heteropteran is responsible for transmission, a scientist may be obliged to reconfirm results or repeat experiments (e.g., Mathen et al. 1990).

The economic importance of heteropteran vectors is uncertain. Presently, diseases caused by Phytomonas spp. are restricted to phloem necroses in a few South American crops. However, expanded cultivation in Brazilian Amazônia may lead to further transmission of flagellates from native plants to economically important crops. The high proportion of heteropterans harboring Phytomonas in this region is a potential problem (Godoi et al. 2002). Describing the damage associated with $L$. serpens-infected tomatoes, Camargo (1999) notes wryly "it is possible that only persons interested in Phytomonas pay any attention to these tiny spots". Nonetheless, the question of pathogenicity of fruit trypanosomatids remains unanswered, and the ubiquity of these flagellates in ripe fruits ( 33 species of fruit thus far) represents another source of potential economic loss.

The similarity between phytoplasma and trypanosomatid diseases, first noted by Dollet in 1984, remains relevant today. Both are phloem-restricted, transmitted by piercing-sucking insects, and historically presented difficulties in culturing. For many of these diseases, the vectors are still not known. One approach to vector searches is to "test insects in the same taxonomic grouping as other proven vectors of similar pathogens" (Purcell 1985). Knowledge of true bugs as hosts of such varied phloem pathogens as phytoplasmas, trypanosomes, and phloem-limited bacteria will be valuable in future screening for vector species. But this knowledge alone is not sufficient. Phloem-feeding is essential to transmission of many of the economically important pathogens. Further contributions are very much needed from heteropterists, comparable to the extensive body of work on homopteran feeding behavior, in order to reliably identify the phloem-feeding species.

\section{Acknowledgments}

The original version of this paper was presented as part of a symposium at the XII International Congress of Entomology in Foz do Iguaçu, Brasil, August 2000. I am grateful to the symposium organizers, Antônio R. Panizzi and Carl W. Schaefer, for inviting me to participate, and to Antônio R. Panizzi for suggesting that I prepare the material as a Forum article. Kristi Westover and Astri Wayadande kindly read over parts of the manuscript. A grant from the Winthrop University Research Council partially covered the cost of literature translation. Beyond this, I was dependent on the help provided by my bilingual friends and colleagues, to whom I am immensely grateful: Wolfgang Hoeschele (German), Peter Phillips (Spanish), Sarah Ralston (Portuguese), and Pravda Stoeva-Popova (Russian). Finally, I thank the interlibrary loan personnel at Dacus Library, Ann Thomas and Doug Short, for tirelessly obtaining books and articles.

\section{Literature Cited}

Agrios, G. 1980. Insect involvement in the transmission of fungal pathogens, p. 293-324. In K. Maramorosch \& K. Harris (eds.), Vectors of plant pathogens. New York, Academic Press, 467p.

Agrios, G.N. 1997. Plant pathology, $4^{\text {th }}$ ed. San Diego, Academic Press, 635p.

Amaral, B.F. do Filho \& I.V.M. Cajueiro. 1977. Observações sobre o ciclo biológico de Veneza stigma (Herbst, 1794) Osuna, 1975 (Hemiptera: Coreidae) em laboratório. An. Soc. Entomol. Brasil 6: 164-172.

Ammar, E.D. 1994. Propagative transmission of plant and animal viruses by insects: Factors affecting vector specificity and competence. Adv. Dis. Vector Res. 10: 289-331.

Ark, P.A. 1944. Studies on bacterial canker of tomato. Phytopathology 34: 394-400.

Ashby, S.F. \& W. Nowell. 1926. The fungi of stigmatomycosis. Ann. Botany (London) 40: 69-83.

Ayala, S.C., O.B. de Quintero \& P. Barreto. 1975. Tripanosomátidos de plantas laticíferas y sus insectos transmisores en Colombia y Costa Rica. Rev. Biol. Trop. 23:5-15.

Backus, E.A. 1988. Sensory systems and behaviours which mediate hemipteran plant-feeding: A taxonomic overview. J. Insect Physiol. 34: 151-165. 
Bagga, H.S. \& M.L. Laster. 1968. Relation of insects to the initiation and development of boll rot of cotton. J. Econ. Entomol. 61: 1141-1142.

Beard, R.L. 1940. The biology of Anasa tristis DeGeer with particular reference to the tachinid parasite Trichopoda pennipes Fabr. Conn. Agric. Expt. Sta. Bull. 440: 597-679.

Bextine, B.R. 2001. Insect transmission of Serratia marcescens, the causal agent of cucurbit yellow vine disease. Ph.D. thesis, Oklahoma State University, Stillwater. number of pages.

Bextine, B.R., A. Wayadande, B.D. Bruton, S.D. Pair, F. Mitchell \& J. Fletcher. 2003. Artificial feeding system for the squash bug, Anasa tristis (De Geer) (Heteroptera: Coreidae). Southwestern Entomol. 28: 63-67.

Boher, B., J.F. Daniel, G. Fabres \& G. Bani. 1983. Action de Pseudotheraptus devastans (Distant) (Het., Coreidae) et de Colletotrichum gloeosporioides Penz. dans la développement de chancres et de la chute des feuilles chez le manioc (Manihot esculenta Crantz.) Agron. Sci. Prod. Veg. Environ. 3: 989-993.

Bonjour, E.L., W.S. Fargo, J.A. Webster, P.E. Richardson \& G.H. Brusewitz. 1991. Probing behavior comparisons of squash bugs (Heteroptera: Coreidae) on cucurbit hosts. Environ. Entomol. 20: 143-149.

Bruton, B.D., J. Fletcher, S.D. Pair, M. Shaw \& H. SittertzBhatkar. 1998. Association of a phloem-limited bacterium with yellow vine disease in cucurbits. Plant Dis. 82: 512-520.

Bruton, B.D., F. Mitchell, J. Fletcher, S.D. Pair, A. Wayadande, U. Melcher, J. Brady, B. Bextine \& T.W. Popham. 2003. Serratia marcescens, a phloem-colonizing, squash-bug transmitted bacterium: Causal agent of cucurbit yellow vine disease. Plant Dis. 87: 937-944.

Burgess, L. \& D.L. McKenzie. 1991. Role of the insect Nysius niger, and flixweed, Descurainia sophia, in infection of Saskatchewan mustard crops with a yeast, Nematospora sinecauda. Can. Plant Dis. Surv. 71: 37-41.

Burgess, L., J. Dueck \& D.L. McKenzie. 1983. Insect vectors of the yeast Nematospora coryli in mustard Brassica juncea, crops in southern Saskatchewan, Canada. Can. Entomol. 115: 25-30.

Camargo, E.P. 1999. Phytomonas and other trypanosomatid parasites of plants and fruit. Adv. Parasitol. 42: 29-112.

Camargo, E.P. \& F.G. Wallace. 1994. Vectors of plant parasites of the genus Phytomonas. Adv. Dis. Vector Res. 10: 333-359.

Camargo, E.P., P. Kastelein \& I. Roitman. 1990.
Trypanosomatid parasites of plants. Parasitol. Today 6: 22-25.

Canova, A., M.G. Bellardi, A. Bertaccini \& V. Vicchi, 1990. Rosette-disease and witches' broom in sugar beet and spinach in Italy. Phytopathol Mediter. 24: 39-43.

Carter, W. 1973. Insects in relation to plant disease, $2^{\text {nd }}$ ed. New York, Wiley, 759p.

Chandler, L. 1989. The broad-headed bug, Megalotomus parvus (Westwood), (Hemiptera: Alydidae), a dry-season pest of beans in Brazil. Ann. Rpt. Bean Improv. Coop. 32: 84-85.

Chen, J., J. Chen \& X. Xu. 2001. Advances in research of longan witches' broom disease. Acta Hort. 558: 413-416.

Clark, R.G. \& G.E. Wilde. 1970. Association of the green stink bug and the yeast spot disease organism of soybeans. I. Length of retention, effect of molting, isolation from feces and saliva. J. Econ. Entomol. 63: 200204.

Cline, A.R. \& E.A. Backus. 2002. Correlations among AC electronic monitoring waveforms, body postures, and stylet penetration behaviors of Lygus hesperus (Hemiptera: Miridae). Environ. Entomol. 31: 538-549.

Cobben, R.H. 1978. Evolutionary trends in Heteroptera. Part II. Mouthpart-structures and feeding strategies. Meded. Landbouwhogeschool Wageningen 78-5: 1-407.

Conchon, I., M. Campaner, C. Sbravate \& E.P. Camargo. 1989. Trypanosomatids, other than Phytomonas spp., isolated and cultured from fruit. J. Protozool. 36: 412414.

Cook, C.A. \& J.J. Neal. 1999. Feeding behavior of larvae of Anasa tristis (Heteroptera: Coreidae) on pumpkin and cucmber. Environ. Entomol. 28: 173-177.

Coons, G.H., D. Stewart, H.W. Bockstahler \& C.L. Schneider. 1958. Incidence of savoy in relation to the variety of sugar beets and to the proximity of the winter vector Piesma cinerea. Plant Dis. Rep. 42: 502-511.

Crowdy, S.H. 1947. Observations on the pathogenicity of Calonectria rigidiuscula (Berk. and Br.) on Theobroma cacao L. Ann. Appl. Biol. 34: 45-59.

Dammer, K-H. \& H. Grillo. 1990. Verseuchung von Leptoglossus gonagra (Fabr.) mit Nematospora coryli Peglion und Ashbya gossypii (Ashby et Nowell) Guilliermond in einer Zitrusanlage der Republik Kuba. Arch. Phytopathol. Pflanzenschutz. 26: 71-78.

Daugherty, D.M. 1967. Pentatomidae as vectors of leaf spot disease of soybeans. J. Econ. Entomol. 60: 147-152. 
Daugherty, D.M. \& J.E. Foster. 1966. Organism of yeast spot disease isolated from rice damaged by rice stink bug. J. Econ. Entomol. 59: 1282-1283.

Desmier de Chenon, R. 1984. Recherches sur le genre Lincus Stål, Hemiptera, Pentatomidae, Discocephalinae, et son rôle éventual dans la marchitez du palmier à huile et du hart-rot du cocotier. Oléagineux 39: 1-6.

Doi, Y. \& H. Asuyama. 1981. Paulownia witches' broom disease, p. 135-145. In Maramorosch, K. \& S.P. Raychaudhuri (eds.), Mycoplasma diseases of trees and shrubs. New York, Academic Press, 362p.

Dollet, M. 1984. Plant diseases caused by flagellate protozoa (Phytomonas). Ann. Rev. Phytopathol. 22: 115-132.

Dollet, M. 1998. Trypanosomes de plantes/Lutte non polluante. Tropical and subtropical agriculture, $3^{\text {rd }}$ std. Programme, 1992-1995. http://www.agricta.org/pubs/std/ vol1/pages/pdf/077.pdf

Dollet, M., D. Cambrony \& D. Gargani. 1982. Culture axénique in vitro de Phytomonas sp. (Trypanosomatidae) d'Euphorbe, transmis par Stenocephalus agilis Scop. (Coreidae). C. R. Acad. Sci. Paris Série III. 295: 547-550.

Dollet, M., N.R. Sturm, J-C. Ahomadegbe \& D.A. Campbell. 2001. Kinetoplast DNA minicircles of phloem-restricted Phytomonas associated with wilt diseases of coconut and oil palms have a two-domain structure. FEMS Microbiol. Letters 205: 65-69.

Dolling, W.R. 1984. Pentatomid bugs (Hemiptera) that transmit a flagellate disease of cultivated palms in South America. Bull. Entomol. Res. 74: 473-476.

Eisbein, K. 1976. Untersuchungen zum elektronenmikroskopischen Nachwies des Rübenkräusel-Virus (Beta virus 3) in Beta vulgaris L. und Piesma quadratum Fieb. Arch. Phytopathol. Pflanzenschutz, Berlin 12: 299-313.

Dollet, M., N.R. Sturm, M. Sánchez-Moreno \& D.A. Campbell. 2000. 5S ribosomal RNA gene repeat sequences define at least eight groups of plant trypanosomatids (Phytomonas sp.): phloem-restricted pathogens form a distinct section. J. Eukaryotic Microbiol. 47: 569-574.

Fernandez-Ramos, C., F. Luque, C. Fernández-Becerra, A. Osuna, S.I. Jankevicius, J.V. Jankevicius, M.J. Rosales \& M. Sánchez-Moreno. 1999. Biochemical characterization of flagellates isolated from fruits and seeds from Brazil. FEMS Microbiol. Letters 170: 343-348.

Fletcher, J.A. \& A. Wayadande 2002. Fastidious vascularcolonizing bacteria. The Plant Health Instructor, Amer. Phytopathol. Soc. DOI: 10.1094/PHI-I-2002-1218-02. http:/
/www.apsnet.org/education/IntroPlantPath/ PathogenGroups/fastidious/.

Fletcher, J., A. Wayadande, U. Melcher \& F. Ye. 1998. The phytopathogenic mollicute-insect vector interface: A closer look. Phytopathol. 88: 1351-1358.

Foster, J.E. \& D.M. Daugherty. 1969. Isolation of the organism causing yeast-spot disease from the salivary system of the green stink bug. J. Econ. Entomol. 62: 424-427.

Franqueville, H. de. 2001. Oil palm bud rot in Latin America: Preliminary review of established facts and achievements. CIRAD. http:www.burotrop.org/pdf/palmrot/pdf.

Frazer, H.L. 1944. Observations on the method of transmission of internal boll diseases of cotton by the cotton stainer bug. Ann. Appl. Biol. 31: 271-290.

Freymuller, E., R. Milder, J.V. Jankevicius, S.I. Jankevicius \& E.P. Camargo. 1990. Ultrastructural studies on the trypanosomatid Phytomonas serpens in the salivary glands of a phytophagous hemipteran. J. Protozool. 37: 225-229.

Frosch, M. 1983. Vorkommen und Ausbreitung des Erregers der Latenten Rosettenkrankheit der Rübe (Beta vulgaris) in seinem Vektor Piesma quadratum Fieb. (Heteroptera, Piesmidae). Z. Angew. Entomol. 95: 310-318.

Genty, P., G. Lopez \& D. Mariau. 1975. Dégâts de Pestalotiopsis induit par des attaques de Gargaphia en Colombie. Oléagineux 30: 199-204.

Gibbs, A.J. 1957. Leptomonas serpens n. sp., parasitic in the digestive tract and salivary glands of Nezara viridula (Pentatomidae) and in the sap of Solanum lycopersicum (tomato) and other plants. J. Parasitol. 47: 297-303.

Gibb, K.S. \& J.W. Randles. 1988. Studies on the transmission of velvet tobacco mottle virus by the mirid, Cyrtopeltis nicotianae. Ann. Appl. Biol. 112: 427-437.

Gibb, K.S. \& J.W. Randles. 1989. Non-propagative translocation of velvet tobacco mottle virus in the mirid, Cyrtopeltis nicotianae. Ann. Appl. Biol. 115: 11-15.

Gibb, K.S. \& J.W. Randles. 1990. Distribution of velvet tobacco mottle virus in its mirid vector and its relationship to transmissibility. Ann. Appl. Biol. 116: 513-521.

Gibb, K.S. \& J.W. Randles. 1991. Transmission of velvet tobacco mottle virus and related viruses by the mirid Cyrtopeltis nicotianae. Adv. Dis. Vector Res. 7: 1-17.

Godoi, M. 2000. Phytomonas e outros tripanossomatídeos em insetos no estado de Rondônia - Amazônia Ocidental. Dissertation, Univ. São Paulo, 59p. 
Godoi, M.M.I., M.G. Serrano, M.M.G. Teixeira \& E.P. Camargo. 2002. A PCR-based survey on Phytomonas (Euglenozoa: Trypanosomatidae) in phytophagous hemipterans of the Amazon region. J. Eukaryot. Microbiol. 49: 275-279.

Goto, M. 1992. Fundamentals of bacterial plant pathology, San Diego, Academic Press, 342p.

Grillo, H. \& M. Alvarez. 1983. Nematospora coryli Peglion (Nematosporaceae: Hemiascomycetidae) y sus trasmisores en el cultivo de los cítricos. Centro Agricola 10: $13-34$

Harris, K.F. 1977. An ingestion-egestion hypothesis of noncirculative virus transmission, p. 165-220. In K.F. Harris \& K. Maramorosch (eds.), Aphids as virus vectors. New York, Academic Press, 559p.

Harris, K.F. 1981. Arthropod and nematode vectors of plant viruses. Annu. Rev. Phytopathol. 19: 391-426.

Harris, K.F., B. Treur, J. Tsai \& R. Toler. 1981. Observations on leafhopper ingestion-egestion behavior: Its likely role in the transmission of noncirculative viruses and other plant pathogens. J. Econ. Entomol. 74: 446-453.

Harrison, M.D., J.W. Brewer \& L.D. Merrill. 1980. Insect involvement in the transmission of bacterial pathogens, p. 201-276. In K. Maramorosch \& K. Harris (eds.), Vectors of plant pathogens. New York, Academic Press, $467 \mathrm{p}$.

Hiruki, C. 1999. Paulownia witches'-broom disease important in East Asia. Acta Hort. 496: 63-68.

Hollay, M.E., C.M. Smith \& J.F. Robinson. 1987. Structure and formation of feeding sheaths of rice stink bug (Heteroptera: Pentatomidae) on rice grains and their association with fungi. Ann. Entomol. Soc. Am. 80: 212216.

Jankevicius, J.V., S.I. Jankevicius, M. Campaner, I. Conchon, L.A. Maeda, M.M.G. Teixeira, E. Freymuller \& E.P. Camargo. 1989. Life cycle and culturing of Phytomonas serpens (Gibbs), a trypanosomatid parasite of tomatoes. J. Protozool. 36: 265-271.

Jankevicius, S.I., M.L. de Almeida, J.V. Jankevicius, M. Cavazzana, Jr., M. Attias \& W. de Souza. 1993. Axenic cultivation of trypanosomatids found in corn (Zea mays) and in phytophagous hemipterans (Leptoglossus zonatus, Coreidae) and their experimental transmission. J. Eukar. Microbiol. 40: 576581.

Kaiser, W.J. \& N.G. Vakili. 1978. Insect transmission of pathogenic xanthomonads to bean and cowpea in Puerto Rico. Phytopathol. 68: 1057-1063.
Kastelein, P. \& E.P. Camargo. 1990. Trypanosomatid protozoa in fruit of Solanaceae in southeastern Brazil. Mem. Inst. Oswaldo Cruz 85: 413-417.

Kirk, P.M. et al. 2004. IndexFungorum. www.indexfungorum.org, accessed August 2004.

Koizumi, M. 1995. Problems of insect-borne virus diseases of fruit trees in Asia. Food and Fertilizer Technology Center, Taipei, Taiwan. http://www.fftc.agnet.org/library/ article/eb417b.html.

Leach, J.G. 1940. Insect transmission of plant diseases. New York, McGraw-Hill, 615p.

Leach, J.G. \& G. Clulo. 1943. Association between Nematospora phaseoli and the green stink bug. Phytopathology 33: 1209-1211.

Lee, F.N., N.P. Tugwell, S.J. Fanna \& G.J. Weidemann. 1993. Role of fungi vectored by rice stink bug (Heteroptera: Pentatomidae) in discoloration of rice kernels. J. Econ. Entomol. 86: 549-556.

Le Pelley, R.H. 1942. The food and feeding habits of Antestia in Kenya. Bull. Entomol. Res. 33: 71-89.

Mann, J. 1969. Cactus feeding insects and mites. U.S. National Mus. Bull. 256: 125-137.

Martin, W.R., Jr., M.P. Grisham, C.M. Kenerley, W.L. Sterling \& P.W. Morgan. 1987. Microorganisms associated with cotton fleahopper, Pseudatomoscelis seriatus (Heteroptera: Miridae). Ann. Entomol. Soc. Am. 80: 251-255.

Martin, W.R., Jr., W.L. Sterling, C.M. Kenerley \& P.W. Morgan. 1988. Transmission of bacterial blight of cotton, Xanthomonas campestris pv. malvacearum, by feeding of the cotton fleahopper: Implications for stress ethyleneinduced square loss in cotton. J. Entomol. Sci. 23: 161168.

Mathen, K., C.P.R. Nair, M. Gunasekharan, M.P. Govindankutty \& J.J. Solomon. 1988. Stylet course of lace bug, Stephanitis typica (Distant) in coconut leaf. Proc. Indian Acad. Sci. 97: 539-544.

Mathen, K., P. Rajan, C.P. Radhakrishnan Nair, M. Sasikala, M. Gunasekharan, M.P. Govindankutty \& J.J. Solomon. 1990. Transmission of root (wilt) disease to coconut seedlings through Stephanitis typica (Distant) (Heteroptera: Tingidae). Trop. Agric. 67: 69-73.

McGhee, R.B. \& F.J. Postell 1982. Transmission of the trypanosomatid flagellate Phytomonas davidi, a symbiont of the Euphorbiacae, by the hemipteran bug, Pachybrachius bilobata scutellatus. J. Protozool. 29: 445-448. 
McPherson, J.E. \& R.M. McPherson. 2000. Stink bugs of economic importance in America north of Mexico. Boca Raton, Florida, CRC Press, 253p.

Mendes, L. 1956. Podridão interna dos capulhos do algodoiero obtida por meio de insetos. Bragantia 15: 911.

Michailides, T.J. \& D.P. Morgan. 1990. Etiology and transmission of stigmatomycosis disease of pistachio in California, p. 88-95. In Calif. Pistachio Industry (ed.), Annu. Rpt. Crop Year 1989-90. Fresno, Calif., 136p.

Michailides, T.J., D.P. Morgan \& D. Felts. 1998. Spread of Botryosphaeria dothidea in central California pistachio orchards. Acta Hort. 470: 582-591.

Michailides, T.M. \& D.P. Morgan. 1991. New findings on the stigmatomycosis disease of pistachio in California, p. 106-110. In Calif. Pistachio Industry (ed.), Annu. Rpt. Crop Year 1990-91. Fresno, Calif.

Miles, P.W. 1959. The salivary secretions of a plant-sucking bug, Oncopeltus fasciatus (Dall.) (Heteroptera: Lygaiedae) - I. The types of secretions and their roles during feeding. J. Ins. Physiol. 3: 243-255.

Miles, P.W. 1968. Insect secretions in plants. Annu. Rev. Phytopathol. 3: 137-164

Miles, P.W. 1987. Plant-sucking bugs can remove the contents of cells without mechanical damage. Experientia 43: 937-939.

Miles, P.W. \& G.S. Taylor. 1994. 'Osmotic pump' feeding by coreids. Entomol. Exp. Appl. 73: 163-173.

Mitchell, P.L. 1980. Host plant utilization by leaf-footed bugs: An investigation of generalist feeding strategy. Ph.D. dissertation, Univ. of Texas. 226p.

Miyao, G.M., R.M. Davis \& H.J. Phaff. 2000. Outbreak of Erymothecium coryi fruit rot of tomato in California. Plant Dis. 84: 594

Morrill, A.W. 1910. Plant-bugs injurious to cotton bolls. U.S. Dep. Agric. Bur. Entomol. Bull. 86: 1-110.

Nault, L.R. 1997. Arthropod transmission of plant viruses: A new synthesis. Ann. Entomol. Soc. Am. 90: 521-541.

Neal, J.J. 1993. Xylem transport interruption by Anasa tristis feeding causes Cucurbita pepo to wilt. Entomol. Exp. Appl. 69: 195-200.

Neal, J.W., Jr. \& C.W. Schaefer. 2000. Lace bugs (Tingidae), p. 85-137. In Schaefer, C.W. \& A.R. Panizzi (eds.), Heteroptera of economic importance. Boca Raton, CRC Press, 828p.
Nienhaus, F. \& H. Schmutterer. 1976. Rickettsia-like organisms in latent rosette (witches' broom) diseased sugar beet (Beta vulgaris) and spinach (Spinacia oleracea) plants and in the vector Piesma quadratum Fieb. Z. Pflanzenkrankh. Pflanzenschutz. 83: 641-646.

Nyvall, R.F. 1999. Field crop diseases. Ames, Iowa State Univ. Press, 102p.

Okuda, S., Y. Nakano \& T. Natsuaki. 1998. 16S RDNAs of Paulownia witches' broom phytoplasma transmitted by Halyomorpha mista. 7th International Congress of Plant Pathology, Edinburgh. www.bspp.org.uk/icpp98/3.7/ 33.html

Pair, S.D., B.D. Bruton, F. Mitchell, J. Fletcher, A. Wayadande \& U. Melcher. 2004. Overwintering squash bugs harbor and transmit the causal agent of cucurbit yellow vine disease. J. Econ. Entomol. 97: 74-78.

Panizzi, A.R., C.W. Schaefer \& Y. Natuhara. 2000. Broadheaded bugs (Alydidae), p. 321-336. In Schaefer, C.W. \& A.R. Panizzi (eds.), Heteroptera of economic importance. Boca Raton, CRC Press, 828p.

Panizzi, A.R., J.G. Smith, L.A.G. Pereira \& J. Yamashita. 1979. Efeitos dos danos de Piezodorus guildinii (Westwood, 1837) no rendimento e qualidade da soja. An. I Semin. Nac. Pesq. Soja, 2: 59-78.

Phytoplasma-vector.com. 2004. http://www.phytoplasmavector.com/index.htm.

Pollard, D.G. 1973. Plant penetration by feeding aphids (Hemiptera: Aphidoidea): A review. Bull. Entomol. Res. 62: 631-714.

Power, A.G. 2000. Insect transmission of plant viruses: A constraint on virus variability. Curr. Opinion Plant Biol. 3:336-340.

Proeseler, G. 1978. Die akquisitions- und zirkulationszeit des Rübenkräusel-virus. Arch. Phytopathol. Pflanzenschutz, Berlin 14: 95-98

Proeseler, G. 1980. Piesmids, p. 97-113. In K.F. Harris \& K. Maramorosch (eds.), Vectors of plant pathogens. New York, Academic Press, 467p.

Purcell, A.H. 1985. The ecology of bacterial and mycoplasma plant diseases spread by leafhoppers and planthoppers, p. 351-380. In L.R. Nault \& J.G. Rodrigues (eds.). The leafhoppers and planthoppers. New York, Wiley, number of pages.

Ragsdale, D.W., A.D. Larson \& L.D. Newsom. 1979. Microorganisms associated with feeding and from various organs of Nezara viridula. J. Econ. Entomol. 72: 725-727. 
Rascoe, J., M. Berg, U. Melcher, F.L. Mitchell, B.D. Bruton, S.D. Pair \& J. Fletcher. 2003. Identification, phylogenetic analysis, and biological characterization of Serratia marcescens strains causing cucurbit yellow vine disease. Phytopathol. 93: 1233-1239.

Richardson, J.K. 1938. Studies on blackheart, soft-rot, and tarnished plant bug injury of celery. Can. J. Res. (Section D, Zoological Sciences), 16: 182-193.

Ruppel, E.G. 2003. Diseases of beet (Beta vulgaris L.). In American Phytopathological Society (compiler), Common names of plant diseases, APSnet, http://www.apsnet.org/ online/common/names/beet.asp.

Russin, J.S., D.B. Orr, M.B. Layton \& D.J. Boethel. 1988. Incidence of microorganisms in soybean seeds damaged by stink bug feeding. Phytopathol. 78: 306310.

Sbravate, C., M. Campaner, L.E.A. Camargo, I. Conchon, M.M.G. Teixeira \& E.P. Camargo. 1989. Culture and generic identification of trypanosomatids of phytophagous Hemiptera in Brazil. J. Protozool. 36: 543547.

Schaad, N.W., J.B. Jones \& W. Chun (eds.). 2001. Laboratory guide for identification of plant pathogenic bacteria. St. Paul, Minnesota, APS Press, 373p.

Schaefer, C.W. \& A.R. Panizzi (eds.). 2000. Heteroptera of economic importance. Boca Raton, CRC Press, 828p.

Schneider, C.L. 1964. Studies on the transmission of sugarbeet savoy virus by the vector Piesma cinereum (Say). Plant Dis. Rep. 48: 843-845.

Schuh, R.T. \& J.A. Slater. 1995. True bugs of the world (Hemiptera: Heteroptera). Ithaca, New York, Cornell Univ. Press, 336p.

Serrano, M.G., L.R. Nunes, M. Campaner, G.A. Buck, E.P. Camargo \& M.M.G. Teixeira. 1999a. Trypanosomatidae: Phytomonas detection in plants and phytophagous insects by PCR amplification of a genusspecific sequence of the spliced leader gene. Exper. Parasitol. 91: 268-279.

Serrano, M.G., M. Campaner, G.A. Buck, M.M.G. Teixeira \& E.P. Camargo. 1999b. PCR amplification of the spliced leader gene for the diagnosis of trypanosomatid parasites of plants and insects in methanol-fixed smears. FEMS Microbiol. Letters 176: 241-246.
Solarte, R.Y., E.A. Moreno \& J.V. Scorza. 1995. Flageliasis de plantas: Comentarios sobre una revision bibliografica. Rev. Ecol. Lat. Amer. 3:57-68.

Stahl, F.J. \& N.S. Luepschen. 1977. Transmission of Erwinia amylovora to pear fruit by Lygus spp. Plant Dis. Rep. 61: 936-939.

Stephenson, L.W. \& T.E. Russell. 1974. The association of Aspergillus flavus with hemipterous and other insects infecting cotton bracts and foliage. Phytopathol. 64: 15021506

Sweet, M. 2000. Seed and chinch bugs (Lygaeoidea), p. 143264. In C.W. Schaefer \& A.R. Panizzi (eds.), Heteroptera of economic importance. Boca Raton, CRC Press, 828p.

Tanii, A., T. Baba \& T. Haruki. 1974. Bacteria isolated from black rot of rice grains. Ann. Phytopath. Soc. Jpn. 40: 309318 (in Japanese with English abstract).

Turka, I. 1978. Lygus rugulipennis Popp. (Heteroptera: Miridae) vector of potato viruses. Trudy Latv. Lauksaimn. Akad. 164: 65-73 (in Russian with English abstract).

Van Velsen, R.J. \& N.C. Crowley. 1961. Centrosema mosaic: A plant virus disease transmitted by both aphids and plant bugs. Nature 189: 858.

Wallace, F.G. 1966. The trypanosomatid parasites of insects and arachnids. Exper. Parasitol. 18: 124-193.

Wheeler, A.G., Jr. 2001. Biology of the plant bugs (Hemiptera: Miridae): Pests, predators, opportunists. Ithaca, New York, Cornell Univ. Press, 507p.

White, D.T., S.J. Billington, K.B. Walsh \& P.T. Scitt. 1997. DNA sequence analysis supports the association of phytoplasmas with papaya (Carica papaya) dieback, yellow crinkle, and mosaic. Australasian Plant Pathol. 26: 28-36.

Wieczorek, A.M. \& M.G. Wright. 2003. PCR detection of phytoplasma from witches' broom disease on Protea spp. (Proteaceae) and associated arthropods. Acta Hort. 602: $161-166$

Wilkinson, J.D. \& D.M. Daugherty. 1967. Biology of the broadheaded bug Alydus pilosulus (Hemiptera: Alydidae). Ann. Entomol. Soc. Am. 60: 1018-1025.

Wolcott, G.N. 1933. An economic entomology of the West Indies. San Juan, The Entomological Society of Puerto Rico, 688p. 


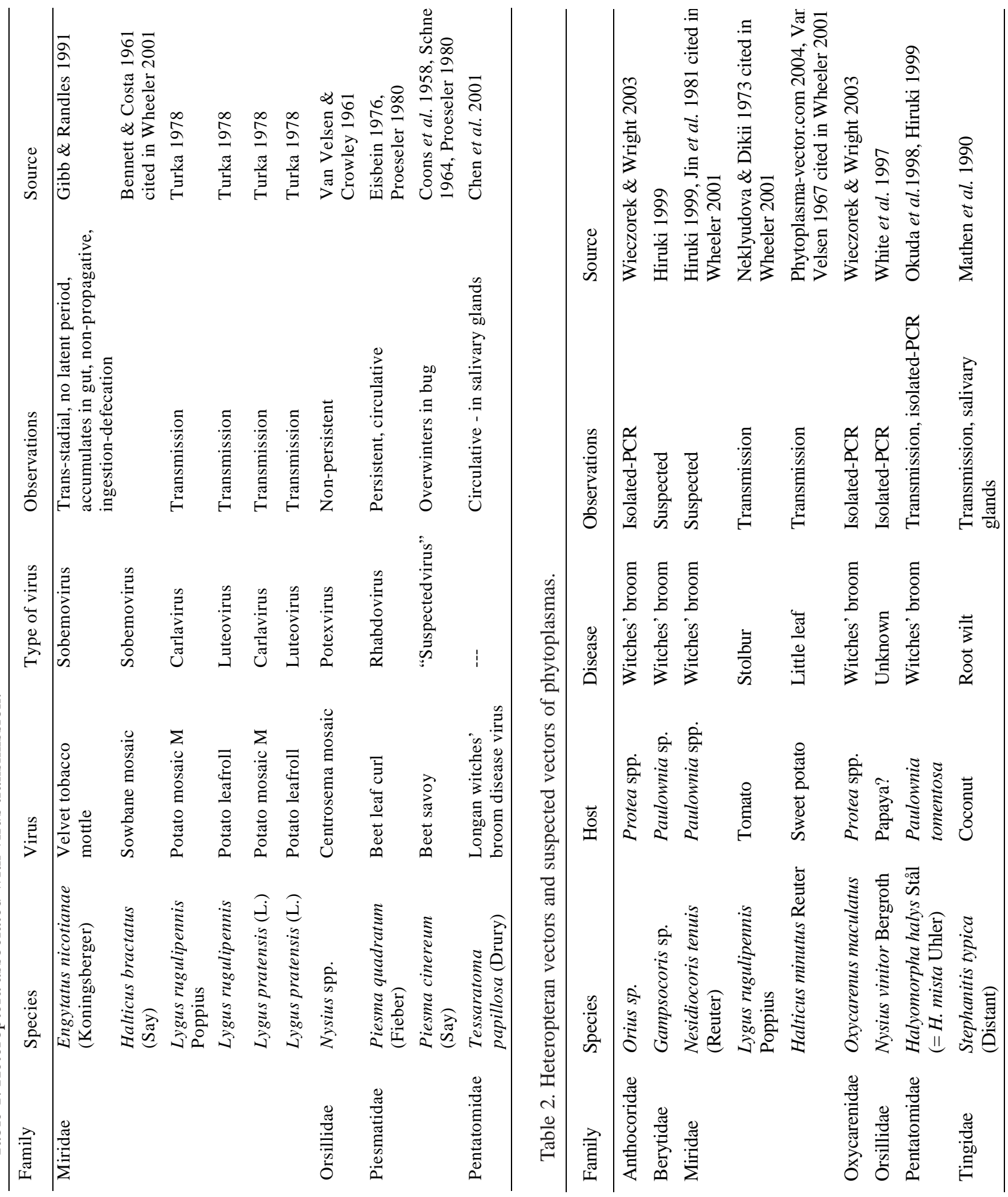




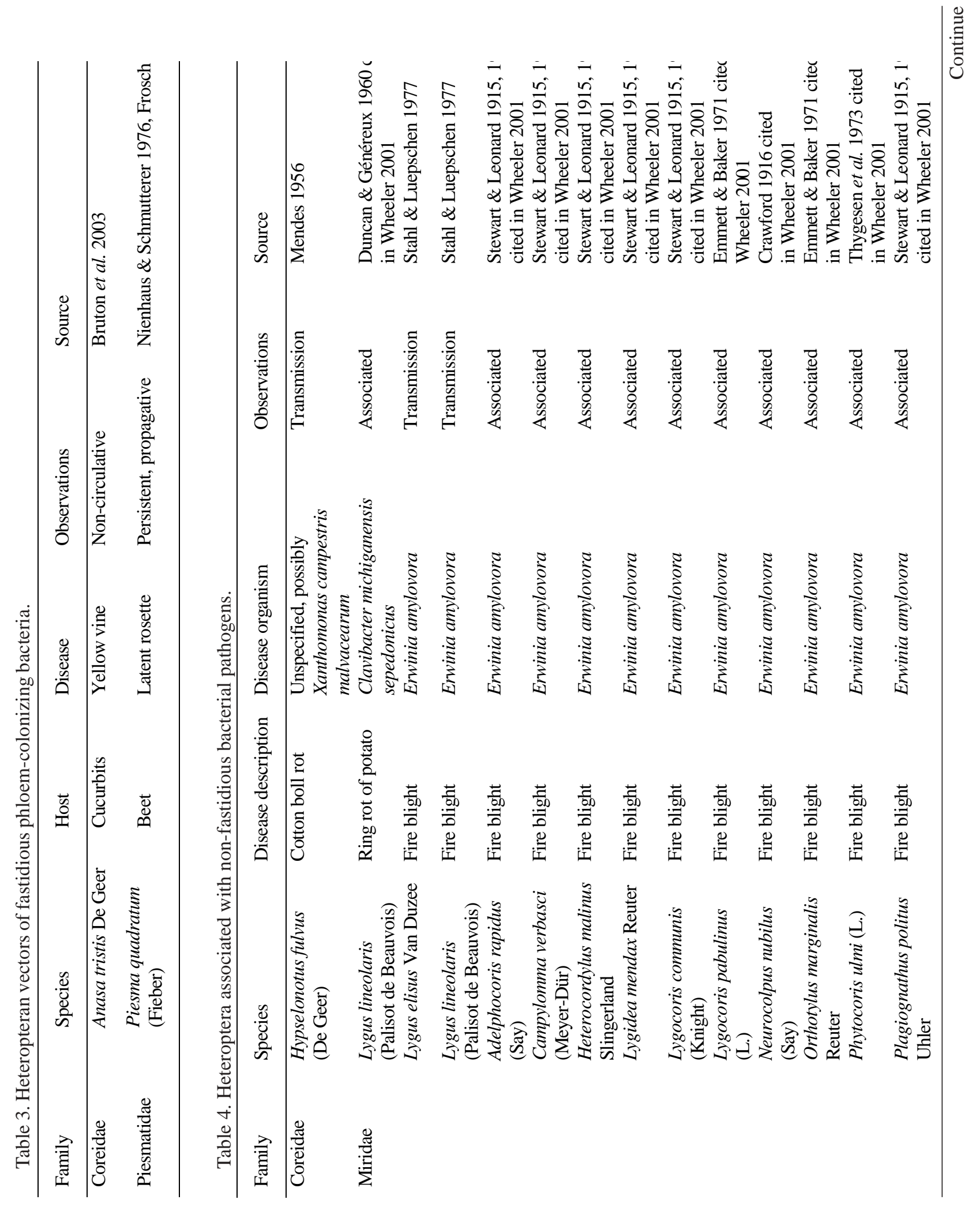




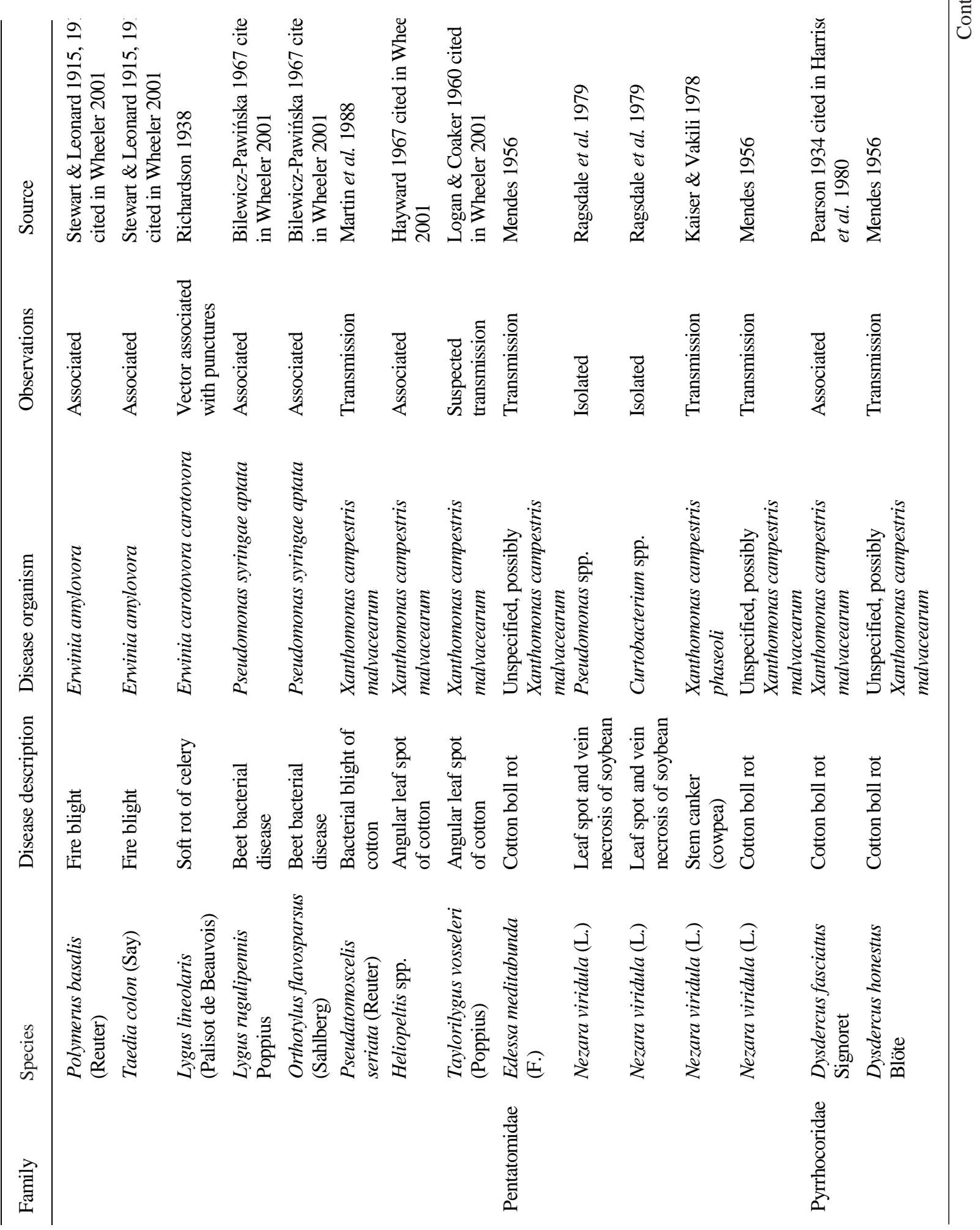



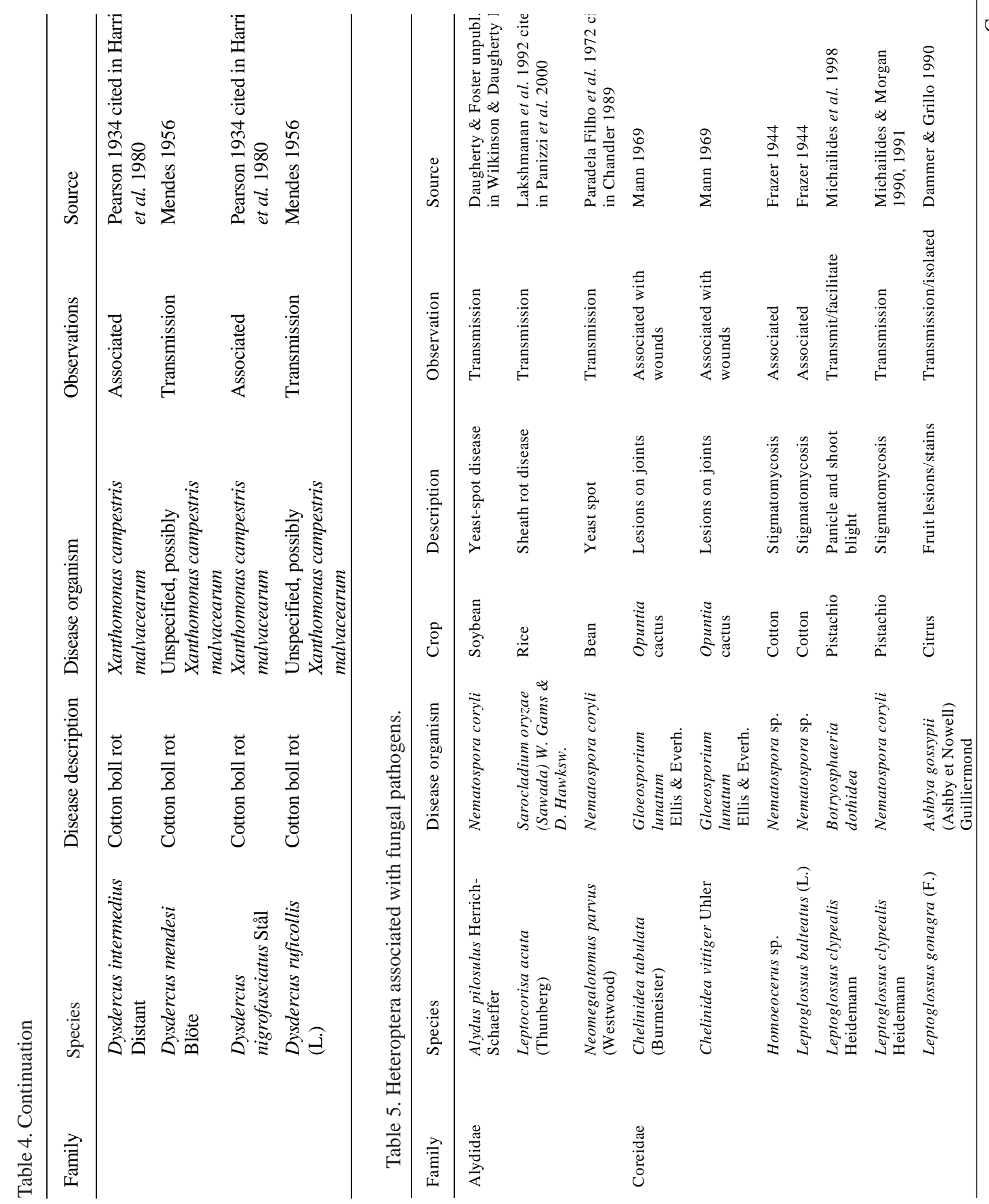


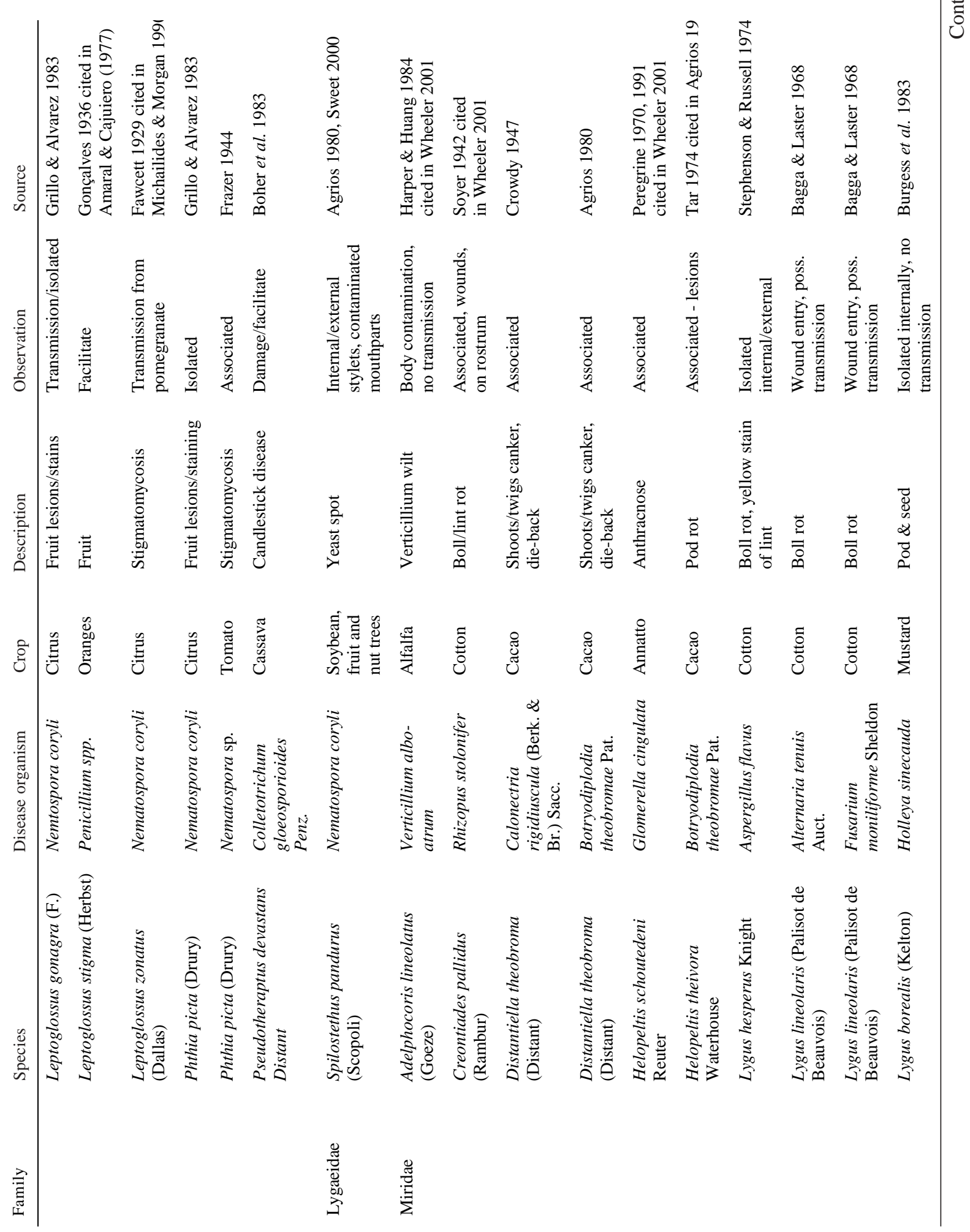




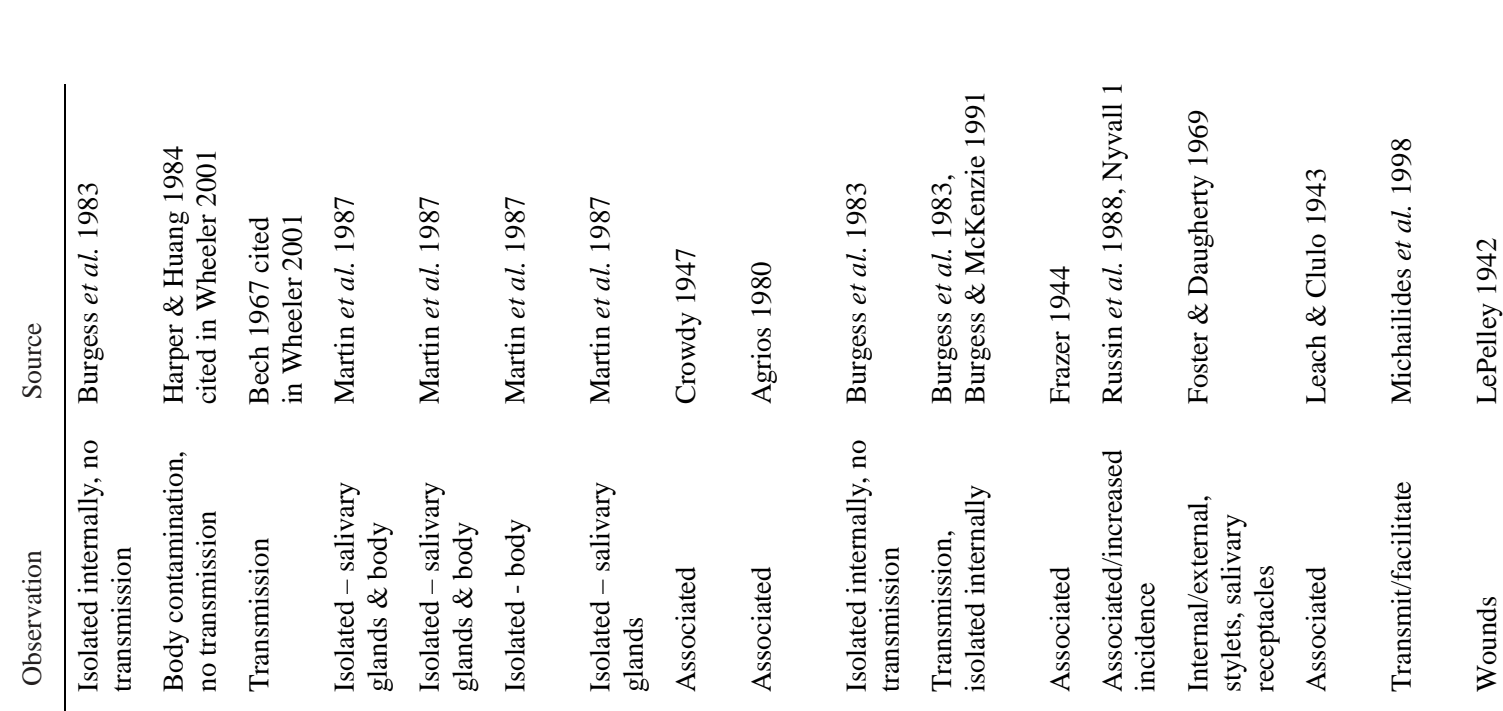

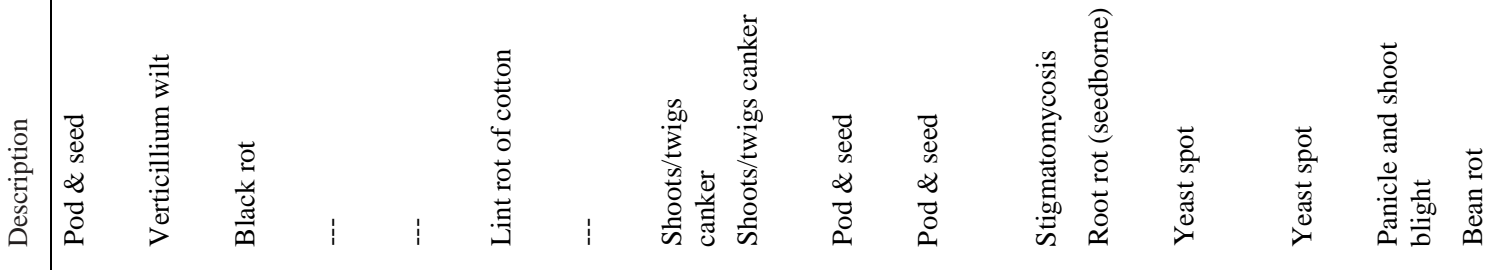

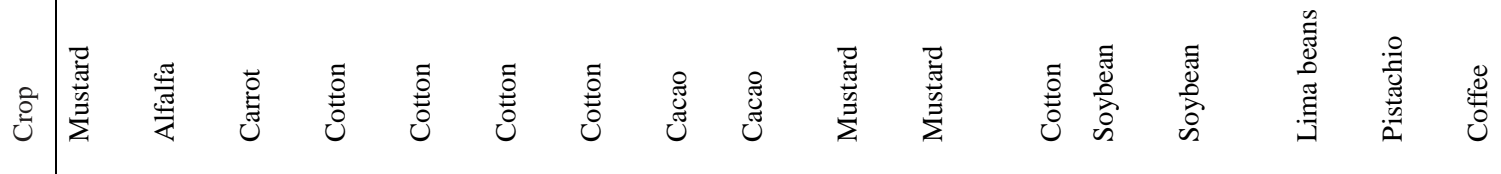

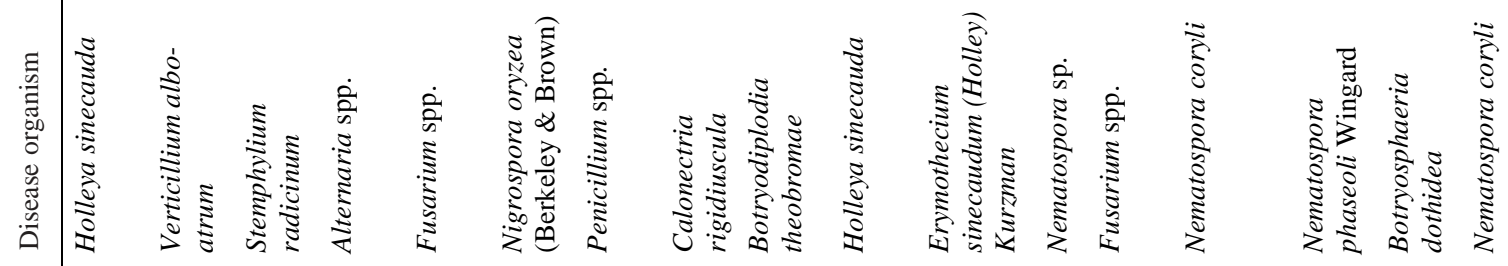

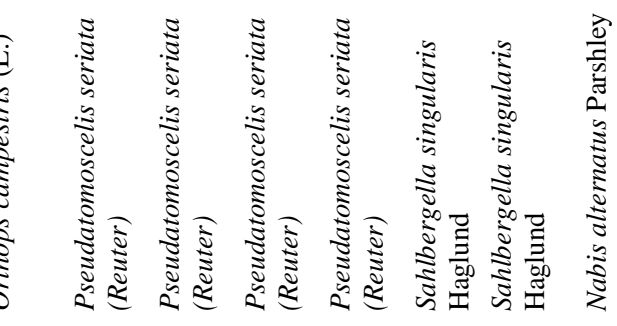

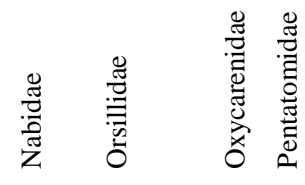




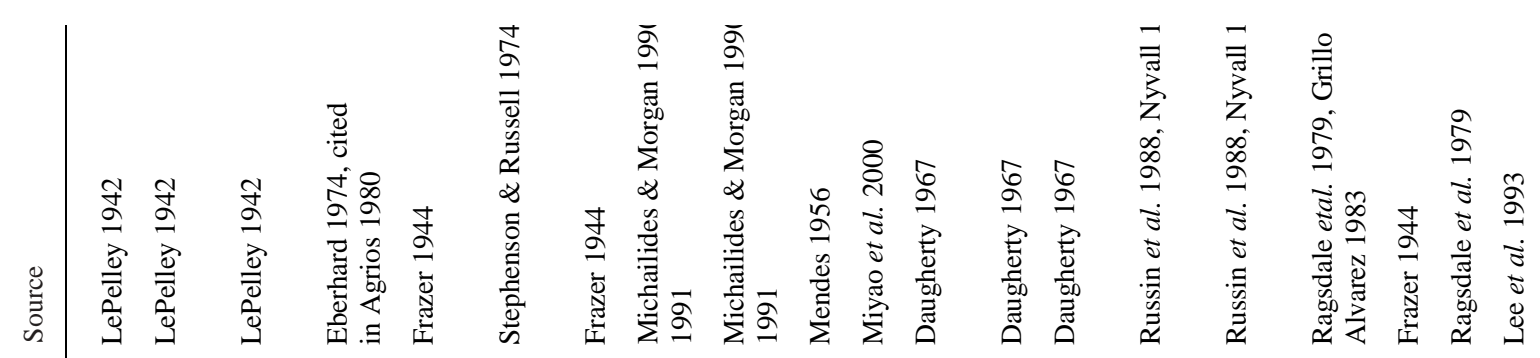

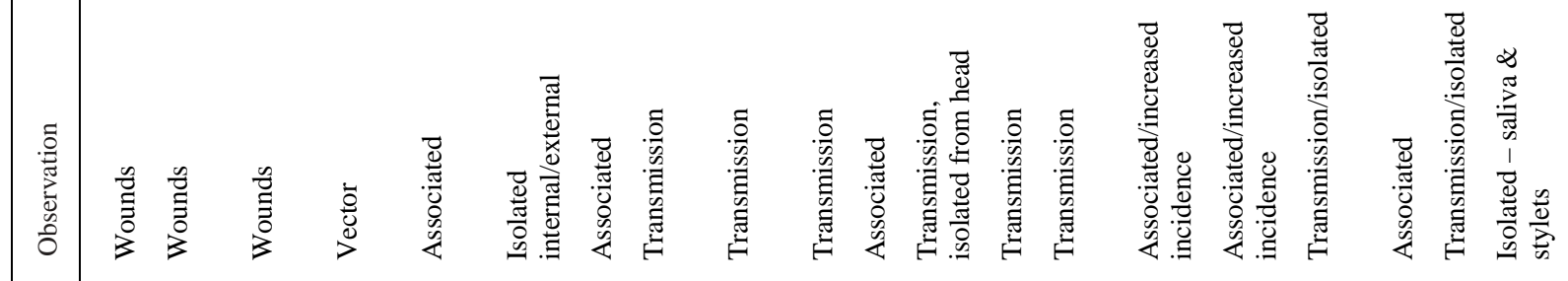

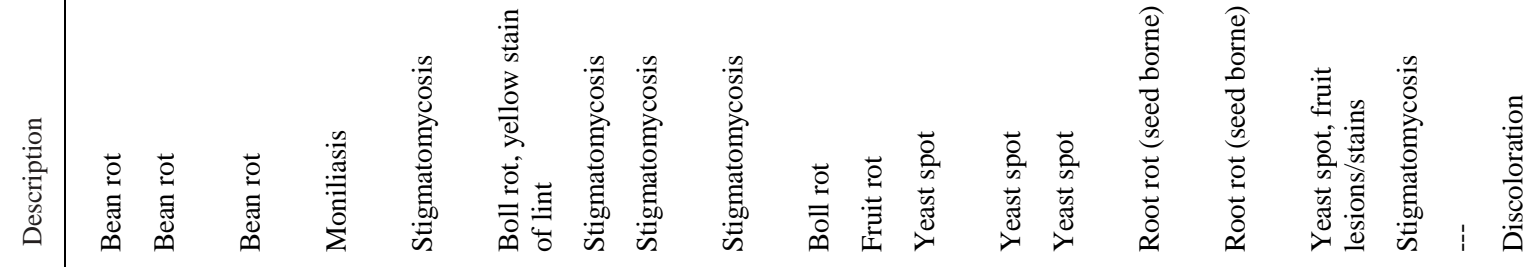

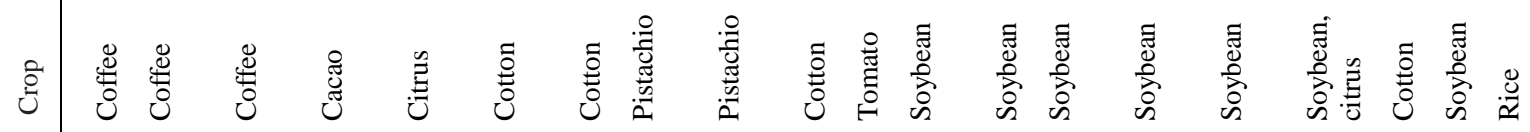

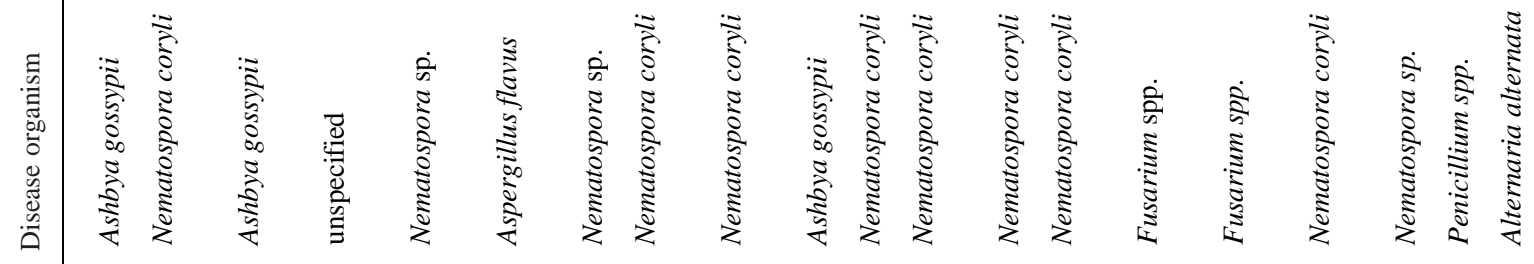

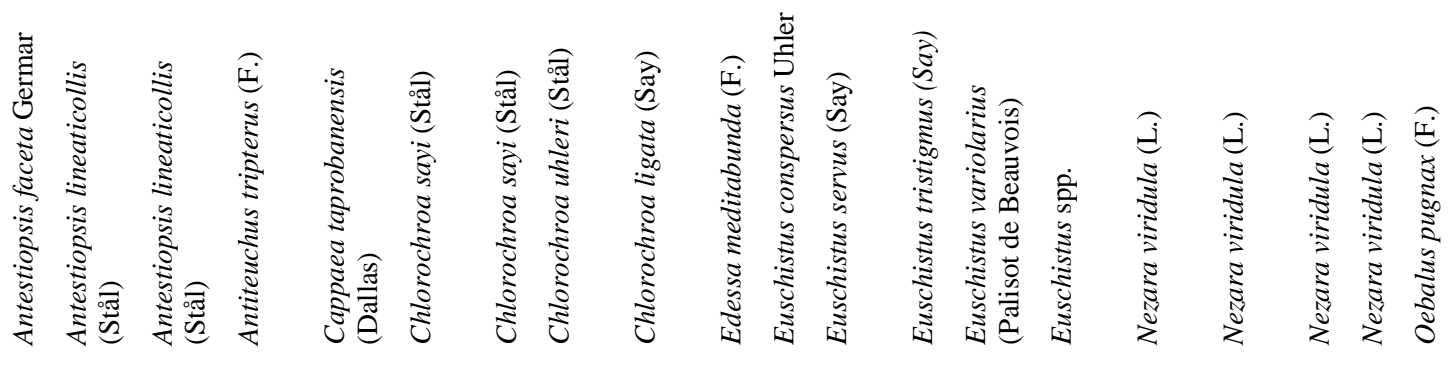




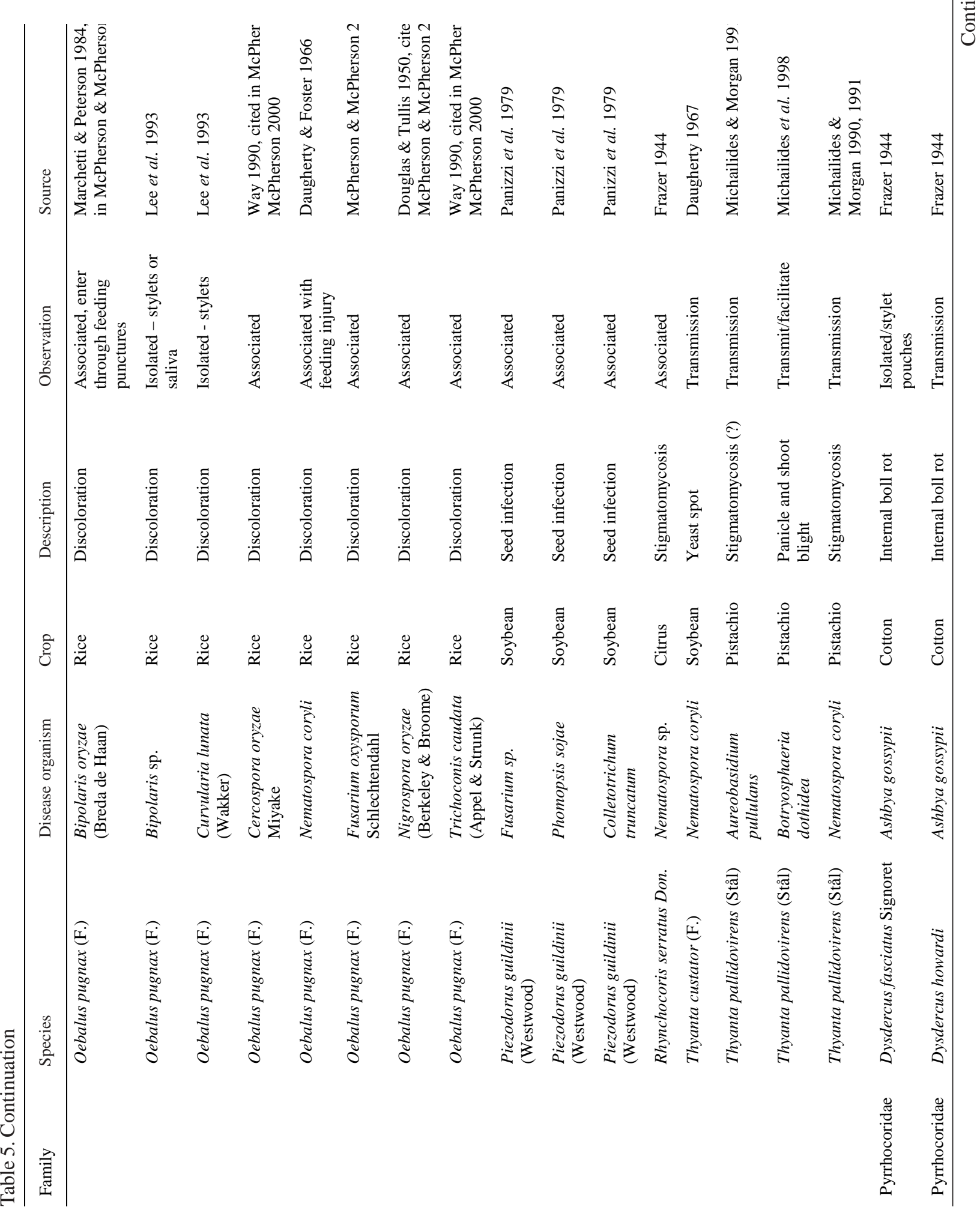




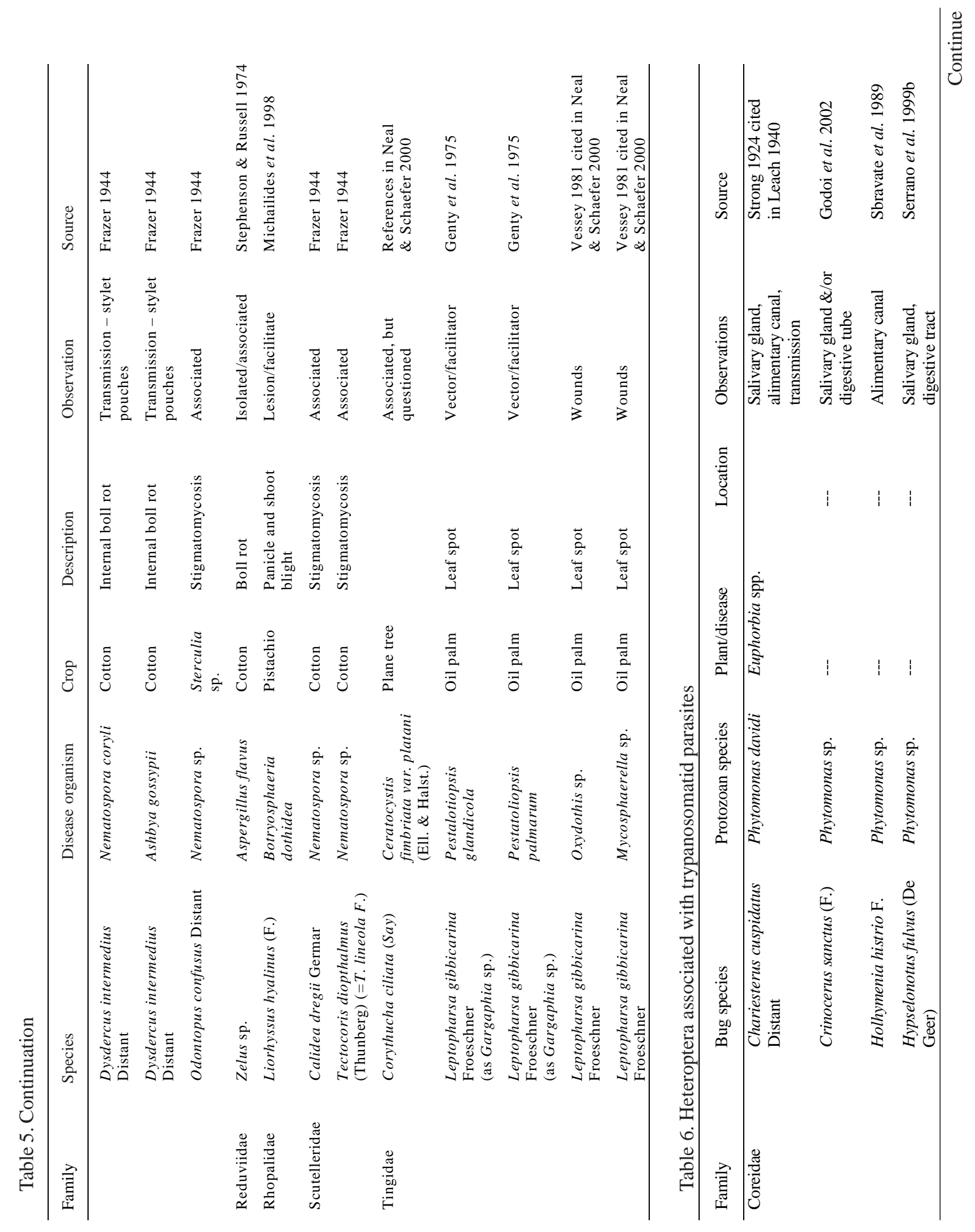




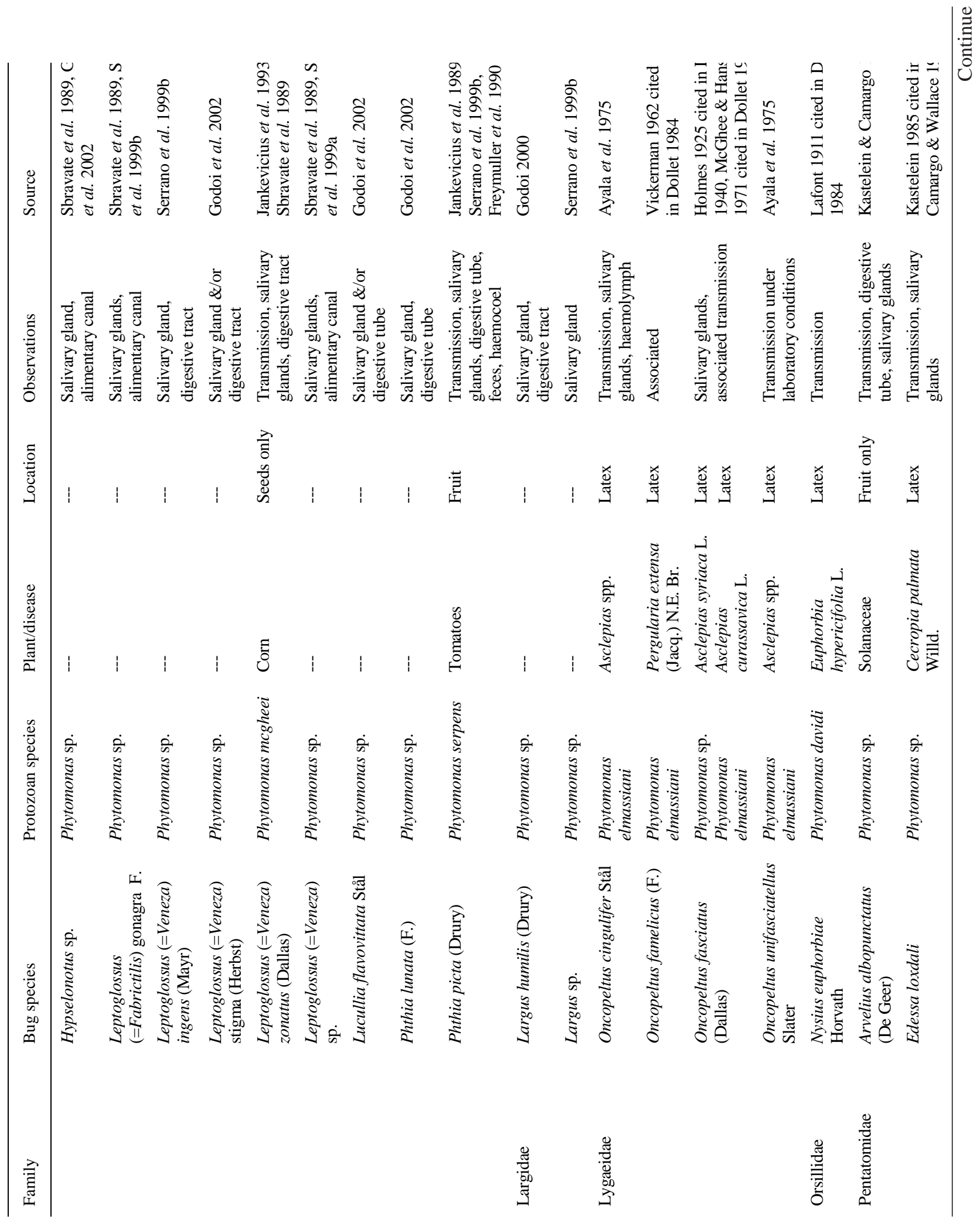




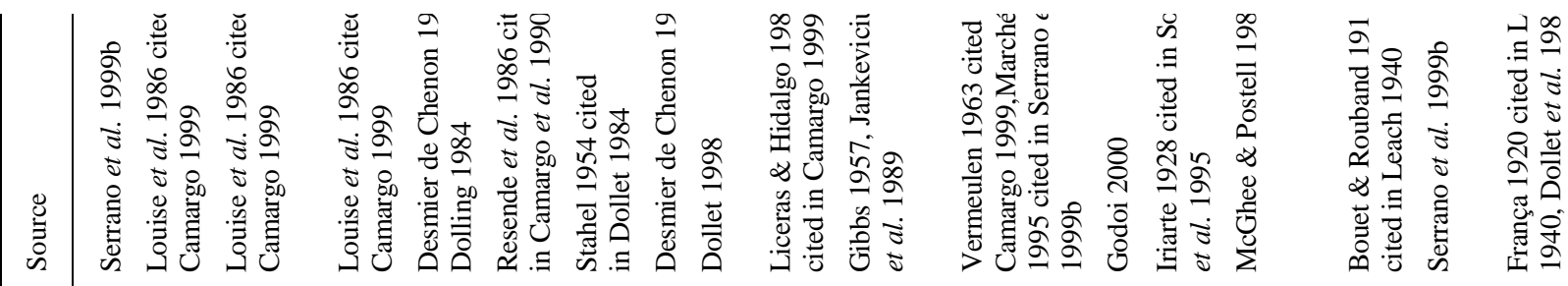

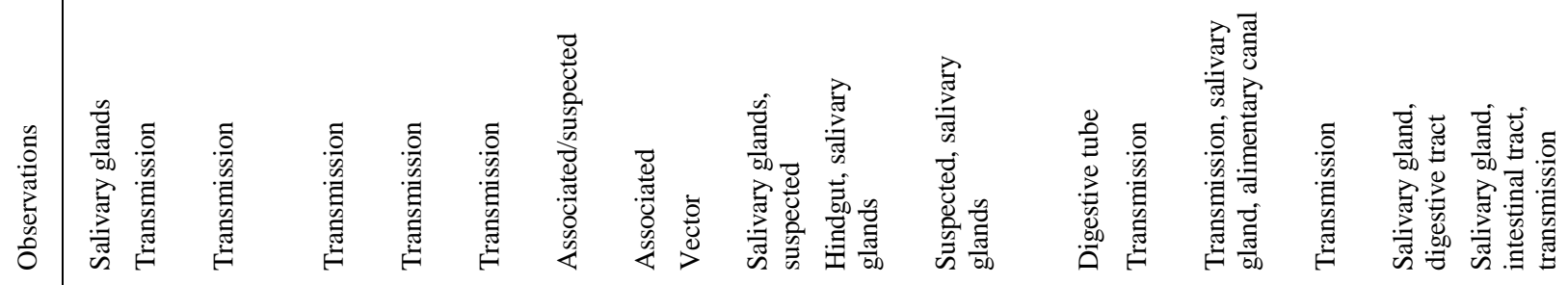

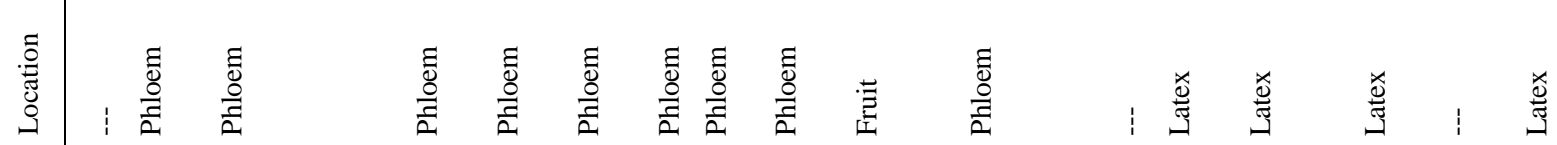

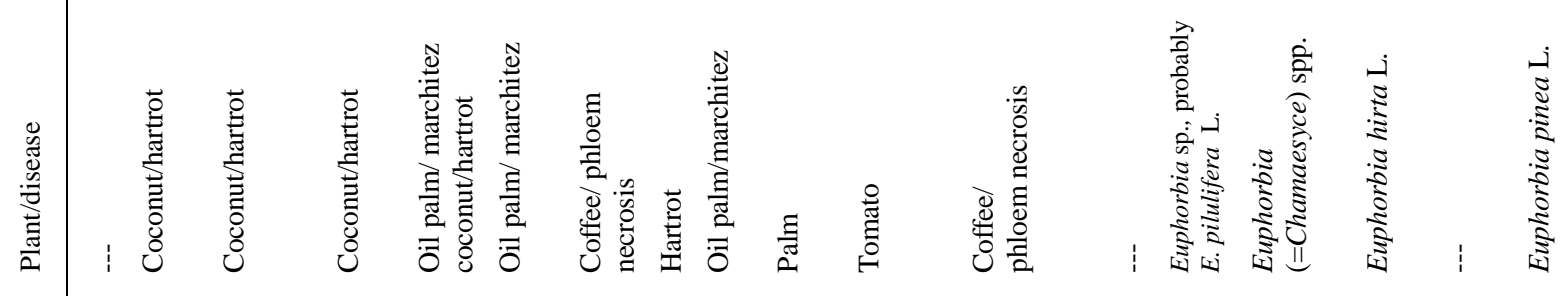

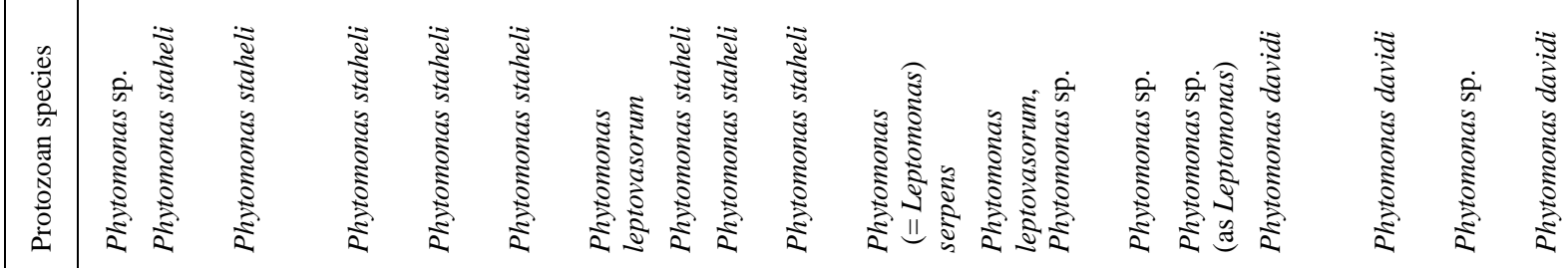

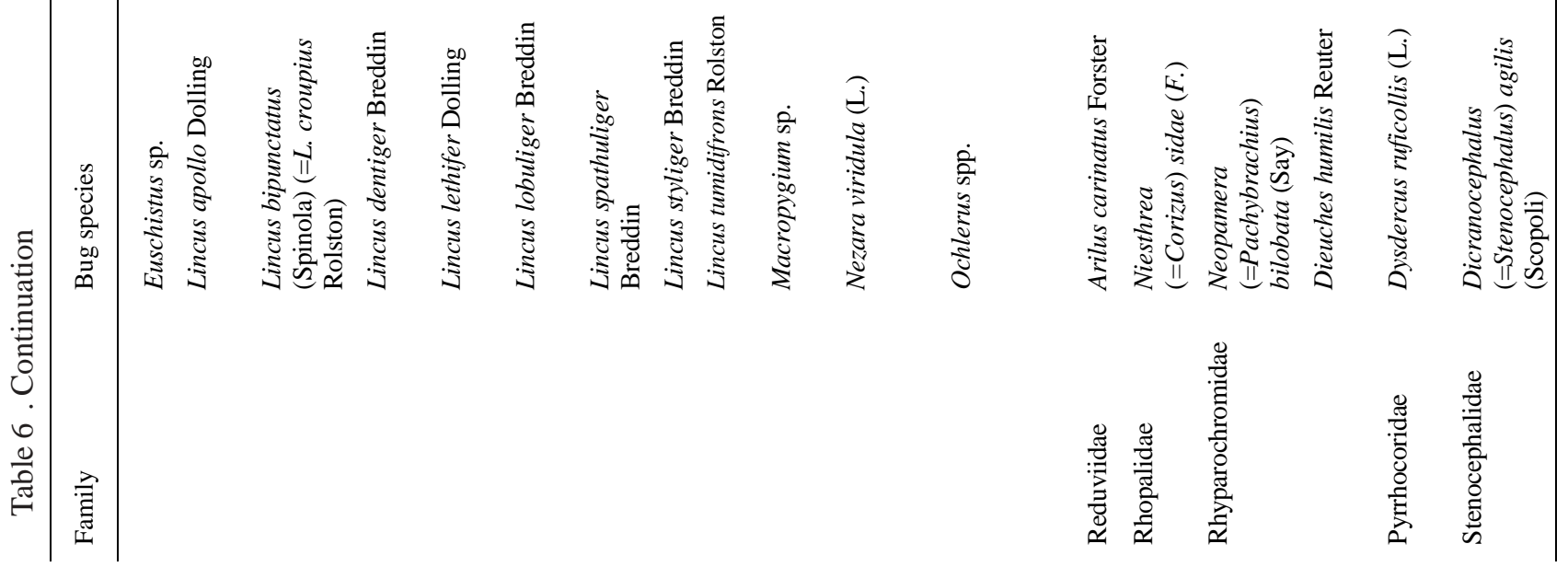

